\title{
LA ITÁLICA DE ADRIANO Resultados de las prospecciones arqueológicas de 1991 y 1993
}

POR

\author{
JOSÉ MANUEL RODRÍGUEZ HIDALGO \\ Consejería de Cultura. Junta de Andalucía
}

SIMON J. KEAY

University of Southampton

DAVID JORDAN

«Terranova», S.L.

J. CREIGHTON

University of Reading

Con la colaboración de ISABEL RODÁ

Universitat Autònoma de Barcelona

\section{RESUMEN}

La prospección geofísica y la recolección sistemática de materiales de superficie dentro de áreas no excavadas de Itálica han puesto al descubierto las plantas de edificios, ahora enterrados, en la Nova Urbs, así como datos sobre su cronología y decoración. Nos confirma que la Itálica de Adriano fue una ciudad excepcional, cuya inspiración debe buscarse en otros centros adrianeos en Oriente. La prospección reveló la existencia de un gran conjunto termal, varios edificios públicos insospechados, un conjunto de calles, mansiones y casas señoriales. Nos sugiere también que el proyecto urbanístico adrianeo nunca se terminó. En época tardoimperial la extensión urbana de Itálica se redujo a un núcleo densamente habitado localizado al Sur del Traianeum y bajo el solar del actual pueblo de Santiponce.

\section{SUMMARY}

A geographical survey and the systematic collection of surface materials within unexcavated parts of Italica has revealed the discovery of plans of hitherto buried buildings in the Nova Urbs, as well as evidence about their chronology and decoration. It has been confirmed that Hadrianic Italica was an exceptional town, the inspiration for much of which is to be sought in other Hadrianic centres in the eastern Empire. The survey revealed the existence of a large baths-palestra complex, several hitherto unsuspected public buildings and a range of undocumented streets, mansions and houses. It also suggests that the Hadrianic projects may never have been completed. In the late years of the Empire Italica had become a walled and densely populated area lying to the south of the Traianeum and beneath the modern village of Santiponce.

\section{ANTECEDENTES Y OBJETIVOS DEL PROYECTO}

Previo a los planteamientos y resultados que ahora presentamos de forma desarrollada, con anterioridad se esbozaron y presentaron algunas imáge- nes y conclusiones de los datos obtenidos en el proyecto de investigación, que sobre la ampliación adrianea de Itálica se efectuó, en su fase de campo, durante los meses de abril de 1991 y de 1993 (Rodríguez Hidalgo, Keay et al., 1993, 1995, 1997)*.

Ahora, antes de entrar en materia, aunque sólo sea de una manera concisa, creemos necesario ilustrar sobre la trayectoria arqueológica del yacimiento, ya que la situación de partida del proyecto es fruto de dos siglos de intervenciones y determinó en gran medida los planteamientos metodológicos del trabajo.

Como resultado de siglos de excavaciones (León, 1993; Rodríguez Hidalgo, 1991) pueden visitarse actualmente en el Conjunto Arqueológico de Itálica (Boletín Oficial de la Junta de Andalucía, 157-89) un amplio espectro de edificios públicos y privados. A pesar de la excepcionalidad de éstos,

* Manifestamos nuestro agradecimiento a tantas personas que con su esfuerzo hicieron posible los resultados expuestos: a los arqueólogos Ana Romo Salas, Juan M. Vargas Jiménez, Nina Keay, Isabel Jordan, Jeremy Taylor. A Dan Sheil, Andy Peina, Seteve Noone y Nick Bradford. A Julian Tealby, John Ditmer, Tania Campbell, del Departamento de Electrónica de la Universidad de York en Inglaterra. A Albert Hesse y Michel Dabas, del Centro de Geofísica del CNRS en Garchy, Francia. Al Profesor Víctor Hurtado y a sus entonces alumnos en el Departamento de Prehistoria y Arqueología de la Universidad de Sevilla.

En lo institucional, a los entonces responsables de la Consejería de Cultura de la Junta de Andalucía, titular del Conjunto Arqueológico de Itálica, y que finnanció el proyecto; al Excmo. Sr. D. Juan Manuel Suárez Japón, Consejero de Cultura; al Ilmo. Sr. D. José Guirao Cabrera, Director General de Bienes Culturales; y al Ilmo. Sr. D. Antonio R. Pozanco León, Delegado Provincial en Sevilla de la Consejería de Cultura. 
hasta hace poco tiempo resultaba difícil entender el estado original de los mismos y su contexto urbano más amplio (Amores y Rodríguez Hidalgo, 1985). La imagen de la Itálica adrianea era, y en parte aún sigue siendo, el resultado de los intereses científicos de las investigaciones realizadas por los distintos arqueólogos, sin que primase en sus planteamientos de trabajo la concepción urbana frente a la de sus unidades configurativas. En cierta medida esto es explicable porque la Administración de forma genérica no arbitraba los medios y fórmulas necesarias para su conservación e investigación.

A diferencia de otras grandes ciudades, cuyo redescubrimiento ha sido necesario, Itálica nunca perdió su recuerdo histórico. Itálica siempre fue Itálica y siempre estuvo ahí, siendo su presencia y su recuerdo causa de estudio y reflexión. Frente a las citas y referencias históricas, sin embargo los argumentos arqueológicos se fueron diluyendo hasta quedar reducidos a topónimos. En 1298, Alonso Pérez de Guzmán el Bueno recibió, dentro del Repartimiento del Reino de Sevilla, la propiedad del lugar de Santiponce. Poco después, en 1301, fundó el Monasterio Cisterciense de San Isidoro del Campo, posiblemente sobre los más sólidos vestigios de la Itálica cristiana (González, 1951). Desde entonces una parte de Itálica se convirtió en las Eras del Monasterio y la otra, la adrianea, en un amplio olivar con fuerte carga semántica para sus múltiples y fraccionadas propiedades, donde destacaban topónimos de tradición popular (Chisvert, 1987-88) como: «El Palacio», «El Peñasco», «El Hoyo del Caliche», «Los Baños de la Reina Mora», «La Fuente del Moro» y «El Baño».

Teniendo como límite norte al Anfiteatro y al pueblo de Santiponce, asentado desde 1601 en las Eras del Monasterio, como límite sur, desde 1781 hasta 1960 en ese olivar efectuaron sus excavaciones Francisco de Bruna, el Mariscal Soult, el Duque de Wellington, Ivo de la Cortina, Demetrio de los Ríos, A. M. Huntington, Rodrigo Amador de los Ríos, A. Parladé, F. Collantes de Terán y J. de Mata Carriazo (Caballos, Marín y Rodríguez Hidalgo, 1999).

El conocimiento de estas excavaciones, especialmente el de los hallazgos escultórios y epigráficos (García y Bellido, 1949), hilvanados con el texto de Dion Casio (69.10.1), le permitió a A. García y Bellido acuñar el término Nova Urbs para expresar la homogeneidad de cuanto aparecía en ese vasto olivar (García y Bellido, 1960). Con él, García y Bellido resaltó la majestuosidad y riqueza de lo exhumado, destacando junto a la monumentalidad de los edificios, tanto públicos como privados, la potencia- lidad de un urbanismo ortogonal de amplias calles, fruto todo ello de la munificencia del emperador Adriano. Crea así un término para referirse a la ampliación adrianea y, en contraposición y contraste, surge una Vetus Urbs anterior. Ambas denominaciones fueron presentadas como una duplicidad de ciudades, de tal modo que investigadores posteriores trataron de buscar y ver los edificios oficiales que ratificaban esa dualidad (Canto, 1976 y AA. VV. 1982).

Las excavaciones que siguieron a la publicación del libro de A. García y Bellido Itálica. Colonia Aelia Augusta, en 1960, ampliaron el entramado del viario (Luzón, 1982) acotaron el espacio urbano con el descubrimiento de parte del lienzo norte de la muralla, el castellum aquae (Pellicer, 1982) y permitieron, sobre todo, el hallazgo del Traianeum (León, 1982 y 1988). En síntesis, éste era el estado arqueológico del yacimiento y, por tanto, ésta era la imagen de la Itálica de Adriano previa al desarrollo de nuestro proyecto.

Para la protección del yacimiento desde el ámbito competencial del Conjunto Arqueológico, el principal objetivo era conocer la extensión, los límites físicos de la ampliación adrianea y poder establecer así las medidas cautelares pertinentes para recogerlas con posterioridad en las distintas figuras de planeamiento urbanístico de Santiponce (Plan Especial, revisión de las Normas Subsidiarias). Igualmente se hacía necesaria la obtención de datos concretos para la elaboración del Documento de delimitación a favor del B.I.C. Zona Arqueológica de Itálica y, posteriormente, para la redacción del Plan Especial del mismo, según se recoge en la actual legislación vigente (Ley de Patrimonio Histórico Español 16/ 1985 y Ley de Patrimonio Histórico de Andalucía 1/ 1991), a través del cual planificar y regular a corto, medio y largo plazo las tareas arqueológicas, así como la presentación al público del yacimiento de una manera más coherente.

Centrados en la investigación, con un planteamiento muy ambicioso por la superficie donde desarrollar el trabajo, nos interesaba conseguir una visión global de lo planificado por Adriano. El objetivo marcado era la ampliación adrianea. La concepción urbanística, frente a los monumentos individualizados era nuestra finalidad. A pesar de las múltiples excavaciones efectuadas durante más de dos siglos, se sabía poco de la densidad de ocupación y habitantes dentro del perímetro amurallado, del equilibrio y relación entre edificios públicos y zonas residenciales, o de la existencia de posibles áreas de producción. Tampoco se sabía de su destino tras el abandono, ni el cómo ni cuándo de éste. 
Con estas premisas nos inclinamos por la realización de un programa combinado de prospecciones que proporcionara respuestas certeras, cuyos objetivos eran:

* Determinar el trazado de la muralla adrianea.

* Determinar la posible ocupación previa del solar antes del proyecto urbanístico de Adriano.

* Determinar la extensión de la cuadrícula urbana y su organización dentro del perímetro amurallado.

* Estimar la densidad de ocupación urbana.

* Estimar el equilibrio entre edificios públicos, el carácter de los mismos y las zonas residenciales o de hábitat.

* Aclarar y fechar el período de abandono.

\section{CONDICIONES DEL ENCLAVE ANTES DE LAS PROSPECCIONES}

Itálica se sitúa sobre una serie de colinas bajas, adyacentes al valle del Rivera de Huelva, un afluente del río Guadalquivir, cuya cuenca se ha sobreelevado considerablemente desde la Antigüedad. Razón ésta por la que muchos de los restos materiales de la antigua Itálica, especialmente los de la vertiente oriental, como el puerto fluvial, áreas de necrópolis y de la calzada interurbana, se encuentran sepultados bajo potentes depósitos de aluvión. La roca base existente bajo la ciudad es una marga blanda, en parte protegida de la erosión por la creación de aterrazamientos, antiguamente como recurso constructivo y posteriormente para mejoras agrícolas.

Las margas son homogéneas, inestables, pobremente drenadas y fáciles de erosionar. Esto produce suelos calcáreos y ricos en arcillas expansivas en las que se han dispersado gran cantidad de residuos arqueológicos, especialmente cerámicos (ánforas, tegulae, etc.) y materiales constructivos de carácter pétreo. En algunas zonas del yacimiento estos restos conforman hasta el $60 \%$ del volumen del suelo, algo usual en una ciudad clásica, aunque en el caso de la ampliación adrianea es tan abundante que constituyó un efecto distorsionador en las propiedades geofísicas del recinto. Determinadas partes del yacimiento han sido también modificadas desde la Antigüedad y muchos restos de edificaciones, especialmente los ubicados en las zonas bajas, permanecen sepultados bajo las tierras arrastradas por efectos de la erosión de la ladera; otros, los que ocupan las cotas más altas, apenas yacen bajo $30 \mathrm{~cm}$ de tierra. Todos ellos están afectados por una variada y prolongada acción antrópica, evidenciándose en al- gunos casos una destrucción y erosión casi completa. Por el contrario, otras edificaciones, aún estando en una ubicación donde cabría esperarse una erosión más activa, han sobrevivido en relativas buenas condiciones. Pero en líneas generales puede afirmarse que el estado de conservación de los restos constructivos de Itálica es malo, debido a que, una vez abandonada la ciudad, sus edificaciones, especialmente las de carácter público, fueron depredadas y sus elementos reaprovechados para nuevas construcciones, convirtiéndose, según consta por la documentación existente, en cantera de materiales constructivos de la vecina Sevilla y poblaciones más próximas, así como en campos de cultivo, especialmente de olivar.

\section{ELECCIÓN DE LA ESTRATEGIA DE TRABAJO}

Desde un principio éramos conscientes de que ninguna técnica por sí sola nos serviría para dar respuesta a las interrogantes formuladas inicialmente. En los últimos 20 ó 25 años dos tipos de trabajo de campo se han venido usando para ampliar el conocimiento de los asentamientos arqueológicos soterrados. Sin tener que emprender excavaciones, la geofísica, especialmente el empleo de la resistividad eléctrica y la magnetometría se han venido utilizando con mayor o menor éxito para detectar estructuras enterradas (Clark, 1990) y la recolección sistemática de material arqueológico en superficie, que hacía tiempo se estaba usando para el estudio de los paisajes rurales y recientemente se está empleando también para investigar recintos urbanos inscritos ahora en un ámbito rural (Bintliff and Snodgrass, 1988).

Para nosotros el ejemplo más próximo e inmediato era Celti (Peñaflor, Sevilla) donde parte del equipo (Keay et al., 1991) experimentó con éxito la combinación de ambas técnicas, corroborando posteriormente los datos obtenidos mediante una excavación en extensión efectuada sobre el foro de la ciudad.

Por un lado las técnicas más comunes de la geofísica nos revelarían un plano donde observar y analizar, individual y conjuntamente, los distintos tipos de estructuras que permanecen en el subsuelo. Así podríamos resolver algunos de los objetivos iniciales; pero sin embargo no nos proporcionarían datos cronológicos y sólo algunos sobre la funcionalidad de las distintas áreas. Por otro, la recolección sistemática superficial nos permitiría realizar un plano de distribución de la densidad de cerámicas y materiales constructivos, al tiempo que nos informaría sobre 
la cronología, decoración y uso de las construcciones enterradas. Por ello, para dar la visión más completa posible de la Itálica de Adriano, se diseñó una estrategia de integración entre las técnicas de prospección sistemática superficial y las geofísicas.

El área de estudio se centró en la ampliación adrianea de titularidad pública. La mayor parte del yacimiento no excavado llevaba años sin tocarse, lleno de maleza y, debido a la naturaleza arcillosa del suelo, la superficie se presentaba extremadamente dura, lo que hacía virtualmente imposible insertar los electrodos del resistivímetro o recolectar material cerámico de superficie. Para subsanar estas dificultades se procedió a gradear el terreno con un tractor, rompiendo y removiendo la superficie hasta una profundidad máxima de $10 \mathrm{~cm}$, asegurándonos de que ninguna estructura soterrada se viera afectada. Las únicas áreas que se dejaron intactas fueron las inaccesibles, las ya excavadas y las ocupadas con desechos modernos o aquellas donde en otro tiempo se almacenaron restos arqueológicos a la intemperie.

Como punto de partida y base para el registro de toda la información extraída, se realizó un vuelo fotogramétrico digitalizado (E. 1:500), cuyas coordenadas sirvieron para la orientación y trazado de las cuadrículas de trabajo, estableciéndose las dimensiones de la malla en $30 \times 30 \mathrm{~m}$, tanto para la prospección superficial como para la geofísica. El trazado Este-Oeste de la cuadrícula, con una diferencia de $35^{\circ}$ respecto al trazado del viario romano, permitíría evitar posibles confusiones en las anomalías geofísicas.

\section{La Geofísica}

Cada técnica geofísica detecta propiedades físicas diferentes, pudiendo así revelar diferentes aspectos de los restos que permanecen enterrados en un yacimiento arqueológico. Se eligieron tres de entre las muchas técnicas posibles como particularmente apropiadas para emplear en Itálica.

El estudio de resistividad eléctrica mide y dibuja la resistencia ofrecida por los restos sólidos enterrados ante una descarga eléctrica emitida en el suelo. En Itálica se empleó un instrumento simple de dos electrodos que permite detectar estructuras hasta una profundidad de un metro y medio. También se usó la magnetometría, técnica por la que dos sensores magnéticos detectan la mínima distorsión producida en el campo magnético terrestre por los restos cerámicos (muros de ladrillo, hornos y fragmentos cerámicos de entidad). Finalmente se empleó un georradar, instrumento que permite detectar restos arqueológicos mediante la medición de señales de radio reflejadas.

Las tres técnicas, después de procesar miles de medidas tomadas parcialmente en cada una de las cuadrículas de $30 \times 30 \mathrm{~m}$ en que dividimos el yacimiento, proporcionaron planos de los restos enterrados. Todas las lecturas se procesaron mediante una rutina matemática simple y se convirtieron posteriormente en imágenes en la pantalla de ordenador.

Una vez excluidas las zonas ya excavadas o las inaccesibles, como indicamos anteriormente, el área potencialmente disponible para el desarrollo del estudio geofísico era de $324.000 \mathrm{~m}^{2}$, superficie equivalente a la multiplicación de las 360 cuadrículas por los $900 \mathrm{~m}^{2}$ que abarcaba cada una de ellas (30 $\times 30 \mathrm{~m}$ ). En dieciséis días de trabajo, dos equipos con resistivímetros y otro con un magnetómetro analizaron el $100 \%$ de esa superficie.

Los datos geofísicos fueron recogidos automáticamente en un ordenador de campo y procesados matemáticamente al final de cada jornada. Posteriormente eran manipulados linealmente en una escala de 256 valores con un margen del 5\% eliminándose los valores erróneos. Las imágenes obtenidas mediante el magnetómetro se trataron a través de una expansión del histograma, un procedimiento muy simple que mejora el contraste entre los valores altos y bajos, sin cambiar su relación matemática. La imagen única obtenida por resistividad fue procesada mediante la utilización de una serie de rutinas matemáticas, que incluían una expansión del histograma y filtros de media adaptativa y de igualación de los valores centrales a través de la mediana. El objetivo de estos procedimientos es eliminar valores de poco contraste derivados de las pobres condiciones del suelo o de las múltiples variaciones geofísicas causadas por la geología e hidrología del lugar; y también enfatizar los pequeños detalles, clarificando así las anomalías físicas generadas por muros y otras estructuras que permanecen enterradas.

\section{Prospección sistemática superficial}

Los principios que subyacen en esta técnica están bien establecidos (ver, por ejemplo, Haselgrove 1985). Hoy día está unánimente aceptada la existencia de una relación directa entre las estructuras arqueológicas enterradas y los materiales de otros niveles y la superficie. En muchas situaciones, por tanto, un análisis de la distribución de los materiales de superficie puede ilustrarnos sobre la naturaleza de los edificios enterrados y las actividades que se desarrollaban en las distintas áreas de un yaci- 
miento determinado. Estableciéndose diferentes categorías de materiales, con posterioridad, puede elaborarse un mapa de distribución de los mismos. En caso de la Nova Urbs, la ausencia aparente de ocupación significativa después del siglo II y principios del III auguraba que se podría confiar en que la mayoría del material de superficie provenía de los edificios enterrados de la ciudad adrianea. La única fuente posible de contaminación podía venir de la dispersión de los montones de materiales que, procedentes de las excavaciones de los años setenta, quedaban en algunos puntos del recinto. Por fortuna la localización aproximada de esos focos de infección era conocida y pudieron aislarse.

La superficie potencialmente disponible era la misma que para la geofísica; es decir, $324.000 \mathrm{~m}^{2}$. No obstante, en la fase de planificación del proyecto se pensó que la recolección sistemática en el $100 \%$ de la superficie era innecesario. El elemento humano para el trabajo de campo, al igual que el tiempo, era limitado. Tan sólo disponíamos de un mes para la realización de todo el trabajo de campo. Además, la recolección de toda esa superficie habría generado una ingente cantidad de material, que posteriormente habría que identificar, analizar y pesar. Se decidió, pues, hacer un muestreo sobre el $50 \%$ de la superficie disponible. Otros trabajos, como el de Celti, han demostrado que un muestreo de menores porcentajes permite obtener una identificación de amplio espectro y una realidad muy aproximada de las relaciones entre los materiales de superficie y las estructuras soterradas, siempre que la recolección se efectúe de forma controlada.

El muestreo se efectuó sobre 72 unidades de recogida $(30 \times 30 \mathrm{~m})$, organizadas en 7 «transects» que corrían en dirección Este-Oeste dentro de la cuadriculación general del yacimiento. Cada cuadrícula fue prospectada intensivamente por un equipo de 15 personas distanciadas entre sí $2 \mathrm{~m}$, estableciéndose la duración del tiempo de recolección para cada cuadrícula en 10 minutos. Los componentes del equipo tenían instrucciones de recolectar la mayor cantidad posible de material, asegurándose de cubrir la totalidad de la cuadrícula.

El proceso antes descrito establece, al menos hasta ciertos límites, que la distribución espacial de los materiales de superficie sirve para determinar la funcionalidad de las edificaciones enterradas. En una situación ideal, este planteamiento podría haberse corroborado cotejando los datos estadísticos de superficie con aquellos obtenidos en una excavación controlada de un nivel superior de un edificio. Esto no fue posible materializarlo en Itálica. En su lugar, por tanto, se llevó a cabo un estudio y pros- pección más intensiva, con una malla de $3 \times 3 \mathrm{~m}$, dentro de una cuadrícula de $30 \times 30 \mathrm{~m}$ ubicada en la «Casa de la Cañada Honda». Esta casa tiene excavada la mitad de su superficie, quedando por excavar la mitad trasera. Excavada en 1973 (Luzón, 1982) y sin haberse efectuado en ella ninguna tarea de restauración o consolidación, mantenía aún restos cerámicos en el nivel superficial de la parte excavada, que fueron cotejados con los depositados en la superficie aún sin excavar. El análisis directo de los materiales y su similitud avaló el método que estábamos desarrollando en la superficie de toda la ampliación adrianea.

Una vez completada la recolección sistemática, comenzó el análisis de los materiales de superficie. Los materiales de construcción más voluminosos, como trozos de mosaico, ladrillos, mármol y segmentos de columnas fueron contados, pesados y depositados nuevamente en su lugar de origen. Tan sólo se retiraron fragmentos de mármol para que los analizara la Profesora. I. Rodá (Universidad Autónoma de Barcelona). El resto del material se lavó, pesó, contó y clasificó. Primero, según el material y función; después, por cronología.

Posteriormente la información extraída de cada cuadrícula sirvió para la elaboración de los mapas de distribución de materiales de superficie, que ilustran sobre el reparto espacial de la cerámica en términos de funcionalidad y cronología, así como su relación con las diferentes edificaciones, públicas o privadas, existentes en el yacimiento.

\section{RESULTADOS DEL PROYECTO}

\section{LA Geofísica}

Los resultados de la prospección geofísica se presentan como imágenes en las que la resistividad y las medidas del magnetómetro se representan en tonos de grises. Los valores altos son más claros y los bajos más oscuros. Las imágenes se sometieron a un mínimo proceso para eliminar errores y clarificar resultados. Esto supone reemplazar los valores aislados extremos, que suelen ser errores, por el promedio de las lecturas más próximas. Las imágenes «limpias» se simplificaron posteriormente mediante un proceso de «suavizado», que combina cada lectura con la media de los valores colindantes, lo que clarifica y contrasta los restos arqueológicos frente al trasfondo geofísico natural. Este efecto combinado reduce la dureza en la imagen de variaciones locales complejas, y enfatiza las bandas arqueológicas que representan estructuras enterradas intactas. 


\section{CLASIFICACIÓN DE MATERIALES}

\begin{tabular}{|c|c|c|}
\hline Cerámica de & $\begin{array}{l}\text { Cocina } \\
\text { Cerámica común } \\
\text { Morteros }\end{array}$ & \\
\hline Vajilla de & $\begin{array}{l}\text { Mesa } \\
\text { Vidrio } \\
\text { Cerámica fina }\end{array}$ & \\
\hline Vajilla de & $\begin{array}{l}\text { Almacenaje } \\
\text { Dolia }\end{array}$ & \\
\hline Vajilla de & $\begin{array}{l}\text { Transporte y Almacenam } \\
\text { Ánforas }\end{array}$ & iento \\
\hline Material de & $\begin{array}{l}\text { Construcción } \\
\text { Teselas } \\
\text { Opus Caementiciun } \\
\text { Argamasa } \\
\text { Estuco } \\
\text { Ladrillos y tégulas } \\
\text { Segmentos de columnas } \\
\text { Opus Signinum } \\
\text { Mármol }\end{array}$ & $\begin{array}{r}700 \mathrm{gr} \\
11.000 \mathrm{gr} \\
1.500 \mathrm{gr} \\
300.000 \mathrm{gr} \\
944 \mathrm{gr} \\
7.600 \mathrm{gr}\end{array}$ \\
\hline Metal & $\begin{array}{l}\text { Monedas } \\
\text { Fragmentos }\end{array}$ & \\
\hline $\begin{array}{l}\text { Esculturas } \\
\text { Inscripciones }\end{array}$ & & \\
\hline
\end{tabular}

\subsection{La resistividad (fig. 1)}

La imagen obtenida mediante esta técnica ofrece con todo detalle los restos que permanecen enterrados, posibilitando la identificación de las distintas estructuras y edificaciones (fig. 2). Los resultados procesados nos permiten, desde el punto de vista de la geofísica, distinguir dos áreas o regio-

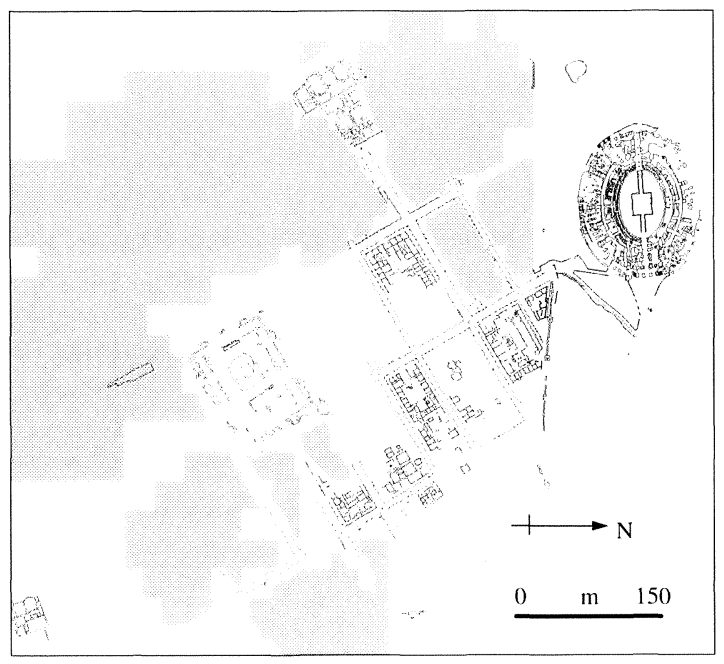

Fig. 1.- Restos excavados y ámbito de desarrollo del trabajo geofísico.

\section{CLASIFICACIÓN DE LA CERÁMICA}

\begin{tabular}{llr}
\hline Cerámica Ibérica (Ss. v-r a.C.) & \\
Cerámica fina: & Ibérica & $50 \mathrm{gr}$ \\
Ánforas: & Ibéricas & $0 \mathrm{gr}$ \\
& Púnicas & $0 \mathrm{gr}$
\end{tabular}

Cerámica Republicana (fines del s. III-I a. C.)

$\begin{array}{llr}\text { Cerámica fina: } & \text { Barníz Negro A } & 0 \mathrm{gr} \\ & \text { Barníz Negro B } & 350 \mathrm{gr} \\ & \text { Barníz Negro indeterminado } 0 \mathrm{gr} \\ \text { Cerámica común: } & \\ & \text { Itálica } & 60 \mathrm{gr} \\ & \text { Ánforas itálicas } & 635 \mathrm{gr} \\ & \text { Ánforas béticas } & 365 \mathrm{gr} \\ & \text { Otras africanas } & 0 \mathrm{gr} \\ & 50 \mathrm{gr}\end{array}$

Cerámica Altoimperial

(fines del s. I a.C.-fines s. II d. C.)

\begin{tabular}{|c|c|c|}
\hline Cerámica fina: & $\begin{array}{l}\text { Rojo Pompeyano } \\
\text { T. S. Itálica } \\
\text { T. S. Itálica imitación } \\
\text { T. S. Sudgálica } \\
\text { T. S. Hispánica } \\
\text { T. S. Oriental } \\
\text { T. S. Clara A } \\
\text { T. S. Clara A imitación } \\
\text { Paredes finas }\end{array}$ & $\begin{array}{r}550 \mathrm{gr} \\
50 \mathrm{gr} \\
50 \mathrm{gr} \\
2.350 \mathrm{gr} \\
2.020 \mathrm{gr} \\
150 \mathrm{gr} \\
6.190 \mathrm{gr} \\
1.520 \mathrm{gr} \\
100 \mathrm{gr}\end{array}$ \\
\hline Cerámica común: & $\begin{array}{l}\text { Africana } \\
\text { Africana imitación local }\end{array}$ & $\begin{array}{l}8.235 \mathrm{gr} \\
6.505 \mathrm{gr}\end{array}$ \\
\hline Ánforas: & $\begin{array}{l}\text { Béticas (Dressel 20) } \\
\text { Béticas (Beltrán I-IV) } \\
\text { Africanas } \\
\text { Tarraconenses } \\
\text { Itálicas } \\
\text { Gálicas } \\
\text { Otras }\end{array}$ & $\begin{array}{r}5.005 \mathrm{gr} \\
3.915 \mathrm{gr} \\
250 \mathrm{gr} \\
1.370 \mathrm{gr} \\
1.610 \mathrm{gr} \\
405 \mathrm{gr} \\
3.725 \mathrm{gr}\end{array}$ \\
\hline
\end{tabular}

Cerámica Tardorromana (fines s. II-s. vI)

$\begin{array}{llr}\text { Cerámica fina: } & \text { T. S. Clara C } & 2.300 \mathrm{gr} \\ & \text { T. S. Clara C imitación } & 300 \mathrm{gr} \\ & \text { T. S. Clara D } & 2.805 \mathrm{gr} \\ \text { Ánforas } & \text { Africanas } & \\ & \text { Orientales } & 1.210 \mathrm{gr} \\ & \text { Itálicas } & 50 \mathrm{gr} \\ & \text { Hispánicas } & 150 \mathrm{gr} \\ & & 150 \mathrm{gr}\end{array}$

\section{Material sin identificar}

$\begin{array}{llr}\text { A mano } & \text { Sin identificar } & 3.390 \mathrm{gr} \\ \text { Cerámica común } & \text { Sin identificar } & 191.474 \mathrm{gr} \\ \text { Ánforas } & \text { Sin identificar } & 292.277 \mathrm{gr} \\ & \text { Itálicas varias } & 7.012 \mathrm{gr} \\ & \text { Africanas varias } & 3.185 \mathrm{gr}\end{array}$




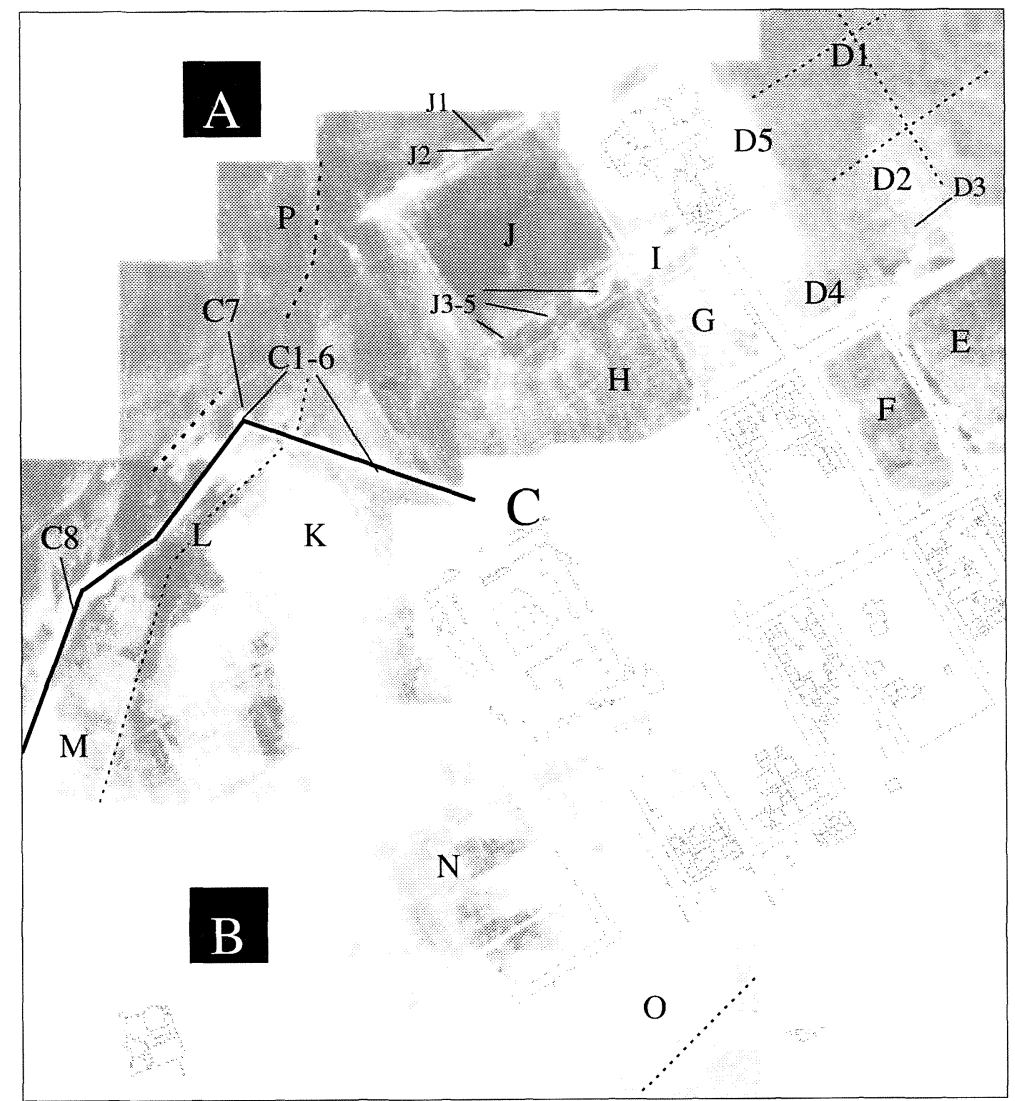

Fig. 2.-Localización e identificación de restos en la prospección de resistencia eléctrica.

nes: A, que tiene una tonalidad más oscura y por tanto de menor resistencia y B. Entre ambas discurre un trazado de resistencia más alta que se interpreta como una potente línea de muralla (C) muy compacta de unos $6 \mathrm{~m}$ de anchura (C1-C6), con una serie de torres, una de ellas haciendo las funciones de puerta, que remata en uno de sus vértices con una potente torre a modo de bastión (C7). La muralla está bien definida, lo que aventura un buen estado de conservación. No obstante, se hace menos nítida a medida que sube hacia el norte, buscando las cotas más elevadas, probablemente debido a la mayor erosión existente en las cotas superiores, que poseen menos depósitos de tierra. Hacia el sureste (C8) se presenta más ancha y menos definida, lo que sugiere que aquí el núcleo de la muralla está difuminado por sus propios derrumbes.

La Región A, además de tener una resistencia general más baja, se presenta menos compleja que la B. Está claramente articulada en un número de bloques bien definidos que corresponden a insulae de ocupación doméstica y edificios públicos de grandes dimensiones.
La parte superior de la Región A, más al nordeste (D) está cruzada por una serie de líneas de mayor resistencia (D1), que discurren por el eje de las calles y que deben interpretarse como cloacas. Colina abajo, hacia el este, se aprecia con bastante claridad un edificio incompleto (D2), posiblemente de carácter público, que tal vez pudo tener un patio (D3). Al sur de esta manzana encontramos un edificio residencial, una domus, muy erosionada (D4).

El límite sur de la Región A está dominado por un «halo» de resistencia más ligera y alta, que dificulta la visión de las estructuras del límite norte del complejo termal o Termas Mayores (D5). Ello está originado posiblemente por la gran concentración de escombros enterrados procedentes del colapso de las Termas, que ha elevado la resistencia eléctrica del terreno circundante.

La insula $\mathrm{E}$ tan sólo contiene unas líneas de resistencia más alta, algo que sorprende poco, porque sabemos que los restos de esta zona fueron prácticamente borrados por la acción antrópica de expolio de la vecina línea de murallas y la fuerte erosión posterior de la ladera. 
La insula $\mathrm{F}$ muestra una débil aunque interpretable línea de muros que definen una estructura interna de edificaciones privadas. La insula parece estar dividida en dos mediente un muro transversal y su mitad oriental cruzada a su vez por una línea de resistencia ligeramente más alta, que se puede interpretar como los restos de un antiguo camino moderno que, atravesando el también antiguo olivar, conducía hacia el Anfiteatro. La insula también muestra una serie de muros que definen ámbitos cuya resistencia ligeramente mayor garantiza un aceptable estado de conservación.

La estructura del edificio que ocupa la insula $\mathrm{G}$, por el contrario, aparece muy nítida, siendo posible distinguir su planta completa. Se trata de una gran domus articulada en torno a un patio central o peristilo al que convergen una serie de estancias. Las líneas de fachadas y calles que la delimitan por el sur y el oeste están igualmente claras y bien definidas. En honor a David Jordan, responsable de la geofísica, esta casa la denominamos desde ahora «Casa de David».

Las edificaciones de la insula $\mathrm{H}$ están mucho peor definidas, aunque se observan claramente los muros. No es posible dibujar con garantías el plano interno de las edificaciones, aunque hay suficientes evidencias como para afirmar que se trata de dos casas. A pesar de la proximidad existente entre las insulae $\mathrm{G}$ y $\mathrm{H}$, contrasta la diferencia de nitidez en la identificación de ambas edificaciones. Es posible que los restos de la insula $\mathrm{H}$ estén más profundos o, simplemente, peor conservados, algo a lo que sólo una excavación arqueológica puede dar respuesta.

El núcleo central y parte de la fachada de la Termas Mayores fueron excavados en 1860 y 1973 respectivamente. La zona I del estudio de resistividad nos permite definir perfectamente la línea de fachada y primera crujía de las Termas con sus correspondientes compartimentaciones. El trabajo de resistividad adicional efectuado en 1993 reveló la existencia de un acueducto subterráneo que conectaba el lado oeste de las Termas con el castellum aquae, situado en el límite más occidental de la ciudad.

Asociado y comunicado mediante una puerta existente en el eje de la mitad sur de las Termas Mayores se encuentra el gran espacio público definido en el área J. Esta nueva edificación es de planta rectangular, de $120 \times 140 \mathrm{~m}$. Se trata de una galería porticada (J1 y J2) con un gran espacio abierto y vacío en su interior. En los muros de fachada de los lados mayores se alternan exedras semicirculares y rectangulares (J3-J5), al igual que sucede en el Traianeum (fig. 3). El espacio interior aparece vacío de estructuras, aunque existen caminos y senderos

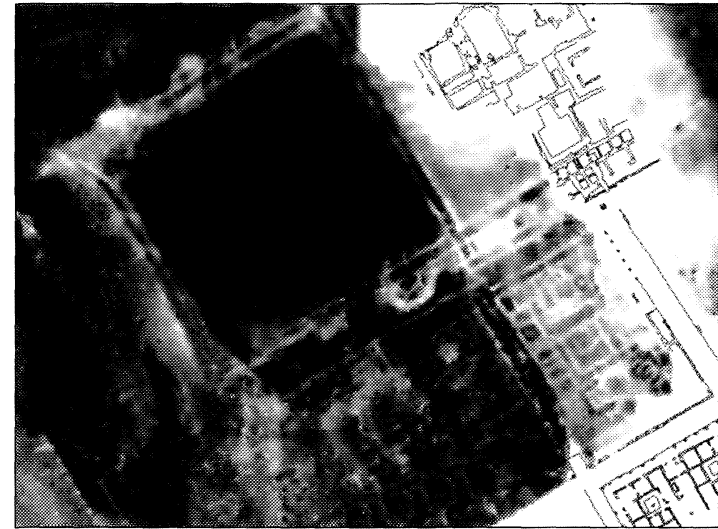

Fig. 3.-Prospección de resistividad. Detalle del Conjunto Termal y «Casa de David».

modernos que interfieren la imagen proporcionada por la geofísica. Al sureste del gran espacio J existen una serie de líneas de alta resistencia que deben corresponder a los últimos restos de calles y edificaciones que sobrevivieron a la erosión en la cima de esta pequeña colina; los más claros se ven hacia el oeste, en la trasera del Traianeum.

Un elemento clave es la débil anomalía (P) que desde su arranque en el sureste, donde comparte trazado inicial (C8) con la muralla $\mathrm{C}$ descrita con anterioridad, corre hacia el oeste en busca del castellum aquae. Se trata, sin duda, de la muralla adrianea, que fue recogida en el plano topográfico levantado por Demetrio de los Ríos en el año 1861.

La Región B contiene una mayor densidad de alta resistencia que la $\mathrm{A}$, de ahí que la imagen esté más clara. Además, la resistencia general de fondo es más alta, debido a una mayor proporción de material y restos constructivos en el subsuelo. Se trata de un área que ha estado profundamente estratificada $\mathrm{y}$, consecuentemente, mejor drenada. Y, puesto que los suelos secos son más resistentes al paso de la corriente eléctrica, las lecturas de resistividad han sido más altas.

Inmediatamente al este del vértice $\mathrm{C} 7$ del muro $\mathrm{C}$ existe una extensa superficie de $80 \times 80 \mathrm{~m}$ de forma semielíptica insertada en un cuadrado $(\mathrm{K})$. Se comporta uniformemente como una zona de muy alta resistencia, algo que sugiere una edificación de carácter público muy sólida y bien conservada (figs. 4 y 5 ).

Al sur de este edificio, en paralelo a la muralla de Adriano, corre una calle (L) que atraviesa la muralla $\mathrm{C}$ por una torre-puerta. Más hacia el este, entre esa calle y el tramo $\mathrm{C} 8$ de la muralla $\mathrm{C}$, se alinean una serie de edificaciones cuya orientación difiere de la del resto de la urbanización adrianea. Se trata de un 


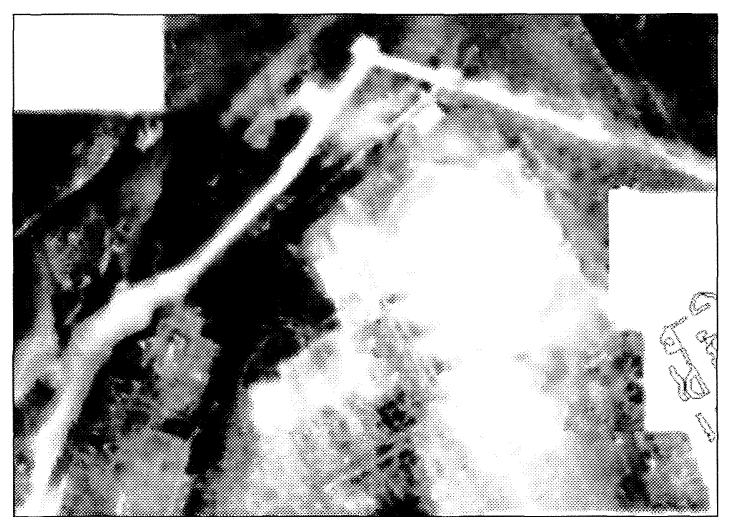

Fig. 4.-Prospección de resistividad. Detalle de la muralla $\mathrm{C}$ y edificio $\mathrm{K}$.

elemento disonante con el resto de la planificación urbanística, pero sin una excavación arqueológica no podemos saber si son estructuras previas, preexistentes a la construcción del barrio adrianeo, o, por el contrario, una reurbanización de aquél.

Por regla general, en la Región B las edificaciones enterradas se presentan densas y resistentes a la corriente eléctrica, probablemente reflejando la gran profundidad de los depósitos de tierra y la mayor concentración de escombros en el subsuelo. Un buen número de calles e insulae enterradas se pueden distinguir en este denso palimpsesto de estructuras. La línea de mayor resistencia $(\mathrm{O})$, que cruza el extremo oriental del área se corresponde formal y funcionalmente con la muralla $\mathrm{C}$ detectada hacia el oeste del yacimiento.

La calidad tan excepcional de las imágenes aportadas por la resistividad eléctrica se debe a varios factores, siendo el más determinante el contraste existente entre la baja resistencia del suelo natural y la alta resistencia de los restos arqueológicos. También ha influido la profundidad a que se encuentran muchos de esos restos y la simplicidad estratigráfica de la fase adrianea de Itálica, porque la ampliación urbanística se ejecutó sobre una superficie virgen de edificaciones, que se abandonó posteriormente, lo que evitó la complejidad de estructuras superpuestas al menos en más de la mitad del proyecto adrianeo. Aún así, afirmamos que los resultados podían haber sido más claros. Una pequeña zona del área a prospectar fue compactada con un rodillo antes de comenzar el estudio, siendo precisamente esa zona, al mejorar el contacto con los electrodos, la que proporcionó la mejor imagen. También, al desarrollarse el estudio sobre una gran superficie $\left(324.000 \mathrm{~m}^{2}\right)$ los restos enterrados se ven en un contexto más amplio, siendo más fácil la interpretación (fig. 6).

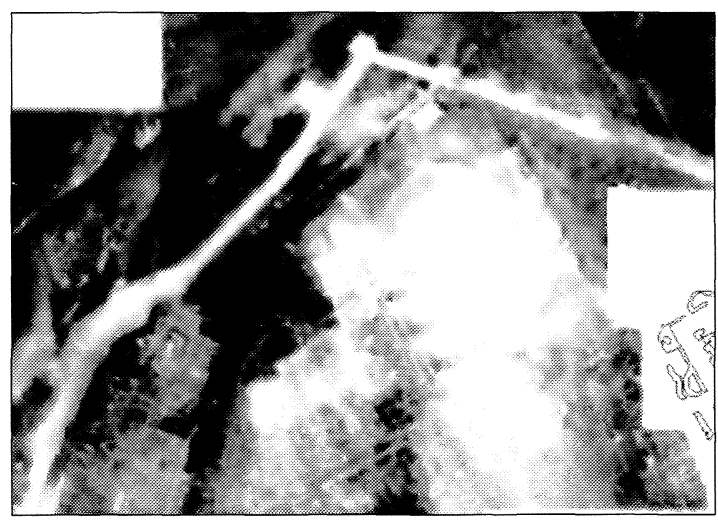

Fig. 5.-Prospección de resistividad. Detalle de la muralla $\mathrm{C}$ y edificio $\mathrm{K}$ clarificados mediante filtraje matemático.

\subsection{Magnetometría}

Los resultados magnéticos cubren un área más restringida, previamente seleccionada para ayudar a conseguir los objetivos del proyecto, aunque proporcionando una información complementaria clave sobre el yacimiento resaltando, igualmente, el potencial del estudio magnético como instrumento de la Arqueología. Normalmente las imágenes magnéticas son mucho más fáciles de interpretar que las del estudio de resistividad, aunque en Itálica, debido a la gran cantidad de residuos cerámicos existentes en el suelo, se produjo un fondo magnético muy ruidoso que dificultó la posibilidad de distinguir los restos arqueológicos de mayor entidad.

Aún así, las imágenes son lo suficientemente nítidas y permiten completar las obtenidas con el resistivímetro. Los casos en que las estructuras reveladas previamente con la resistividad son distinguibles inmediatamente como anomalías magnéticas, se debe a que éstas están provocadas por la presencia de ladrillos en la construcción de los muros.

El contraste entre las denominadas Región A y Región B es, de nuevo, patente. El terreno magnético enormemente alterado de la Región B, manifestado como una densa masa de puntos blancos y negros, oscurece casi todos los detalles de las estructuras enterradas. La Región A, por el contrario, ofrece un buen número de estructuras interesantes, que se relacionan estrechamente con los resultados del resistivímetro. La muralla $\mathrm{C}$ apenas es visible, lo que indica que en su construcción se emplearon más las piedras que los ladrillos. Se puede especular sobre la procedencia de estas piedras, probablemente extraídas de la muralla adrianea $(\mathrm{P})$ y de los edificios públicos de la Región $\mathrm{A}$, que bien po- 


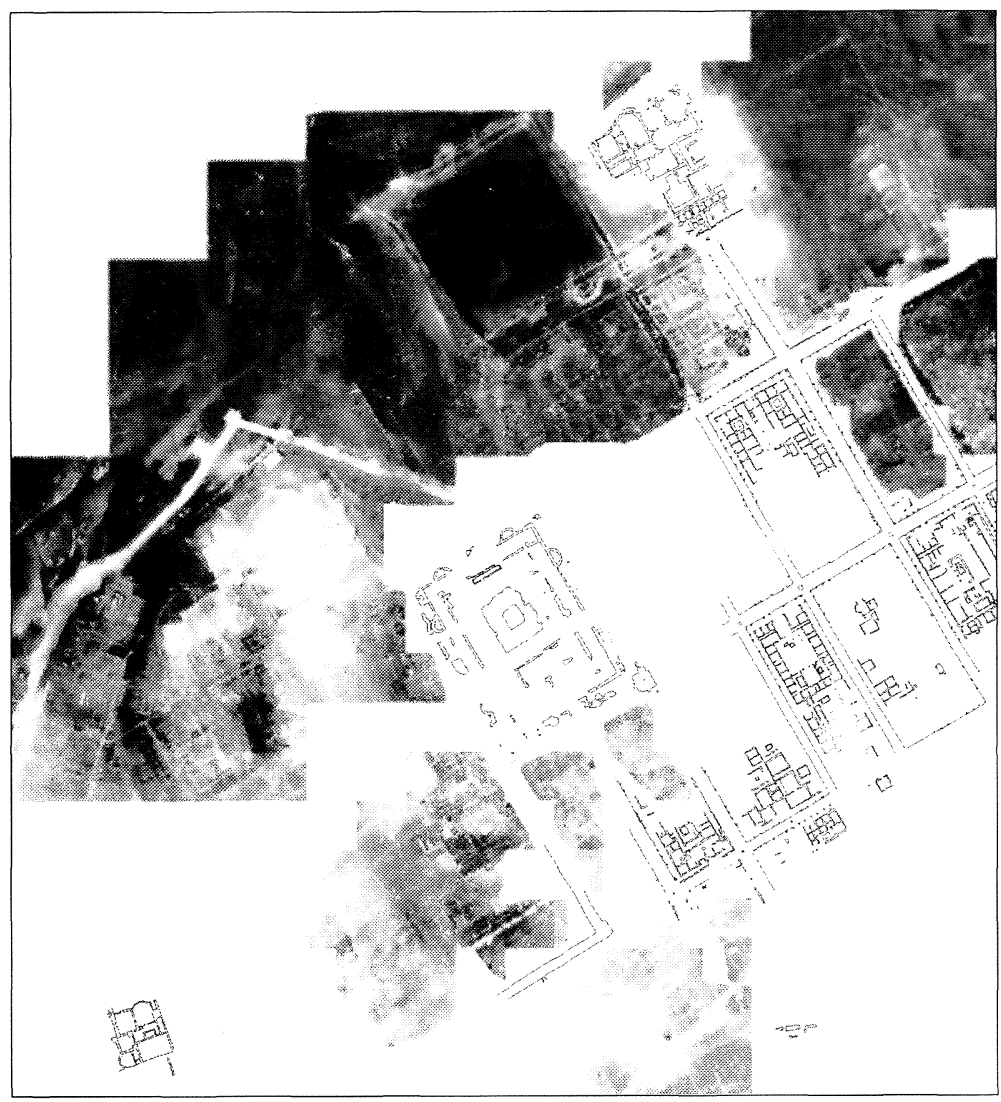

Fig. 6.-Resultados de la prospección eléctrica. Blanco $\geq 80 \Omega$, Negro $\leq 10 \Omega$.

dían haber sido abandonados con anterioridad a la construcción de la muralla $\mathrm{C}$.

Al noroeste de la Región A las líneas de mayor resistencia (D1) aparécen con un color claro. Estas anomalías magnéticas demuestran la presencia de estructuras construidas con ladrillos, algo que confirma su interpretación como cloacas, ya que la mayoría de los desagüies excavados en el yacimiento están construidos con ladrillos. Las edificaciones de las insulae D2 y D4 se presentan como anomalías magnéticas incoherentes. La magnetometría también confirma la ausencia de estructuras conservadas en otras partes del área D. Las insulae $\mathrm{G}$ y $\mathrm{H}$ se muestran muy similares entre sí en cuanto a las distorsiones magnéticas, apareciendo los muros como líneas muy finas. Su imagen no añade nada a lo aportado por la resistividad; no obstante, la similitud de las imágenes de ambas insulae sugiere que el contraste observado en la resistividad puede ser en parte debido a la influencia de las condiciones de la superficie y que, consecuentemente, el edificio $\mathrm{H}$ puede estar tan bien preservado como el G. En las imágenes de magnetometría los muros de fachada de ambas edificaciones se aprecian con más nitidez que en las de resistividad, lo que indica que están ejecutados con ladrillos, cuyos cimientos han sobrevivido casi intactos. En las áreas I y J, las Termas Mayores y su espacio abierto asociado, las anomalías de resistencia están estrechamente relacionadas con las líneas de anomalías magnéticas positivas. Por estar excavadas en parte, sabemos que las caras exteriores de los muros de las Termas Mayores (I) están construidos con ladrillos y macizados con opus caementicium, siendo precisamente los ladrillos los que con esta técnica permiten dibujar con tanta nitidez las imágenes. La continuación de esas anomalías en el edificio J es lo que nos induce a pensar que también sus muros estaban ejecutados con la misma técnica constructiva que las Termas, incluyendo el ábside (J3) que es el que aparece con una anomalía magnética más nítida; seguramente también sea el mejor conservado.

Al sureste de la edificación J, la ausencia de estructuras es patente tanto en la resonancia magnética, como en la resistividad, indicando de nuevo que muchos de los muros enterrados estaban construidos con ladrillos. La cima de la colina (Q) tiene un com- 
portamiento magnético único y distinto al resto del yacimiento. Aquí la base rocosa subyacente ha sido expuesta a la erosión y el suelo carece de restos cerámicos, que producen las distorsiones magnéticas existentes en el el resto del yacimiento (fig. 7).

\subsection{Georradar}

El estudio del georradar abarcó sólo unas pequeñas zonas escogidas y los resultados fueron del todo decepcionantes. Fue casi imposible detectar los muros enterrados, tan claramente visibles por las otras técnicas descritas; quizás debido a que las ondas de radio no pudieron penetrar en el suelo húmedo y calcáreo para alcanzar los restos más profundos. El estudio efectuado sobre las cloacas confirmó que se podían identificar los vacíos, pero poco más. Lo que en otros lugares ha constituido un éxito, aquí no respondió a las exceptativas creadas.

\section{ReColección SistemÁticA DE MATERIALES EN SUPERFICIE}

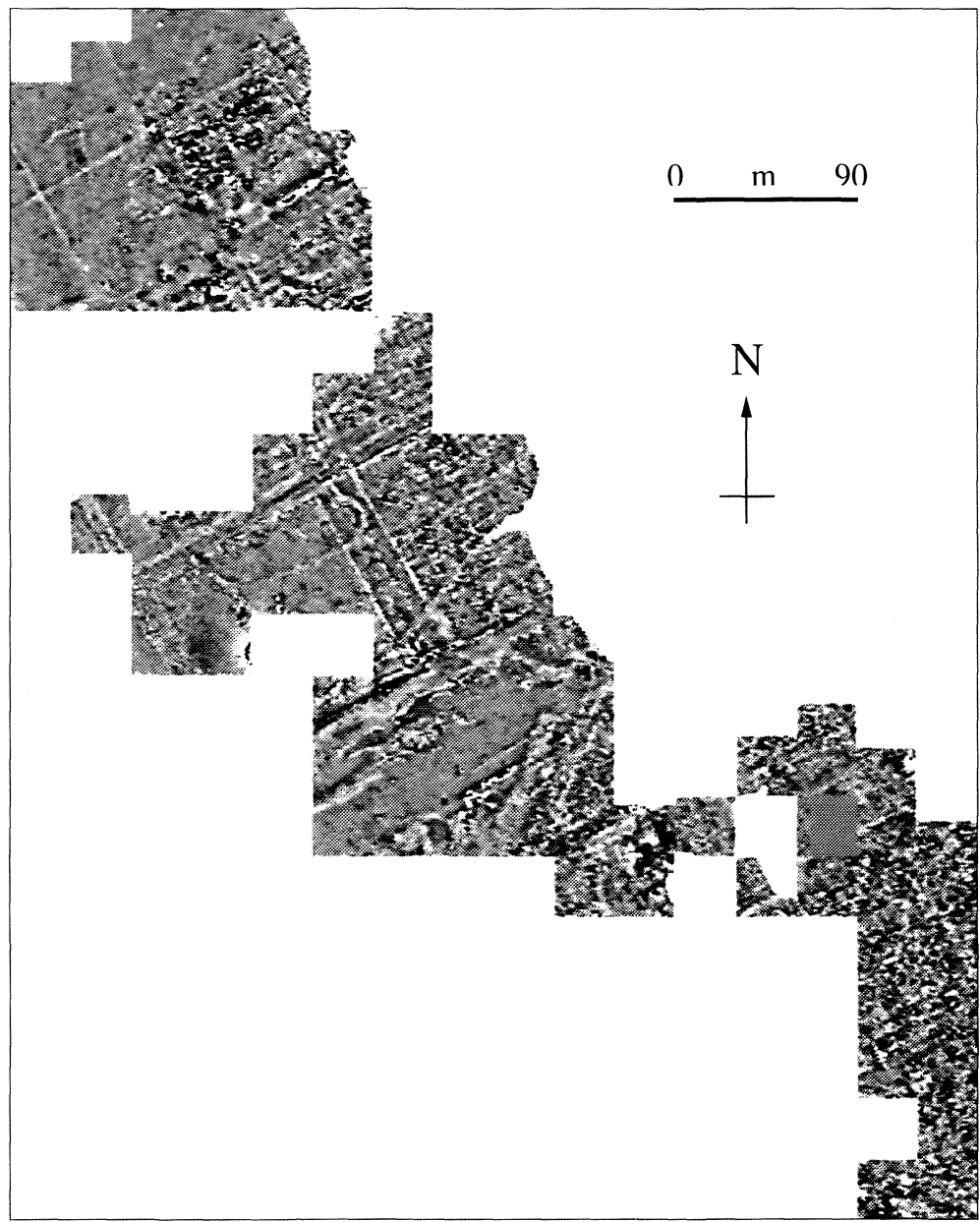

Fig. 7. - Resultados de la prospección magnética. Blanco $\geq 60 \mathrm{nT}$, Negro $\leq 60 \mathrm{nT}$.

La recolección general de todo el yacimiento produjo más de $549 \mathrm{~kg}$ de material cerámico y 322 $\mathrm{kg}$ de material de construcción. Ante este elevado volumen de materiales y la brevedad de la campaña, se decidió que una clasificación visual rápida podría ser la solución. Se sacrificó, hasta cierto punto, la mayor precisión posible del análisis en favor de un estudio más rudimentario, siendo sólo identificados con certeza $52,475 \mathrm{~kg}$ del total de cerámica recolectada.

No hubo dificultad en identificar los fósiles-guía de la cerámica fina de períodos cronológicos concretos, aunque tan sólo un $7 \%$ de las cerámicas comunes pudieron ser identificadas, y un $6 \%$ de los fragmentos de ánforas.

En términos de porcentaje, el $0,28 \%$ de toda la cerámica identificada pertenecería a época ibérica/ republicana; el 83,85\% era Altoimperial, mientras que el el 13,27\% era Tardoimperial. Los datos em- pleados para establecer estos porcentajes se reflejaron posteriormente en unos mapas donde mostrar la distribución de los materiales cerámicos, estableciéndose la densidad de los mismos, en términos de cantidad y peso, mediante una escala de grises y negro, que representa el valor máximo, mientras que el color blanco indica las ausencias. En aquellas cuadrículas que, por el motivo que fuera, fue imposible prospectar su totalidad, los resultados parciales fueron aumentados proporcionalmente hasta alcanzar la escala equivalente a la cuadrícula completa.

\subsection{Material Ibérico}

Durante la prospección superficial tan solo se recolectó un fragmento de 50 gr de cerámica ibérica. Algo curioso si tenemos en cuenta la proximidad de Santiponce, en cuyo subsuelo existe una potente 


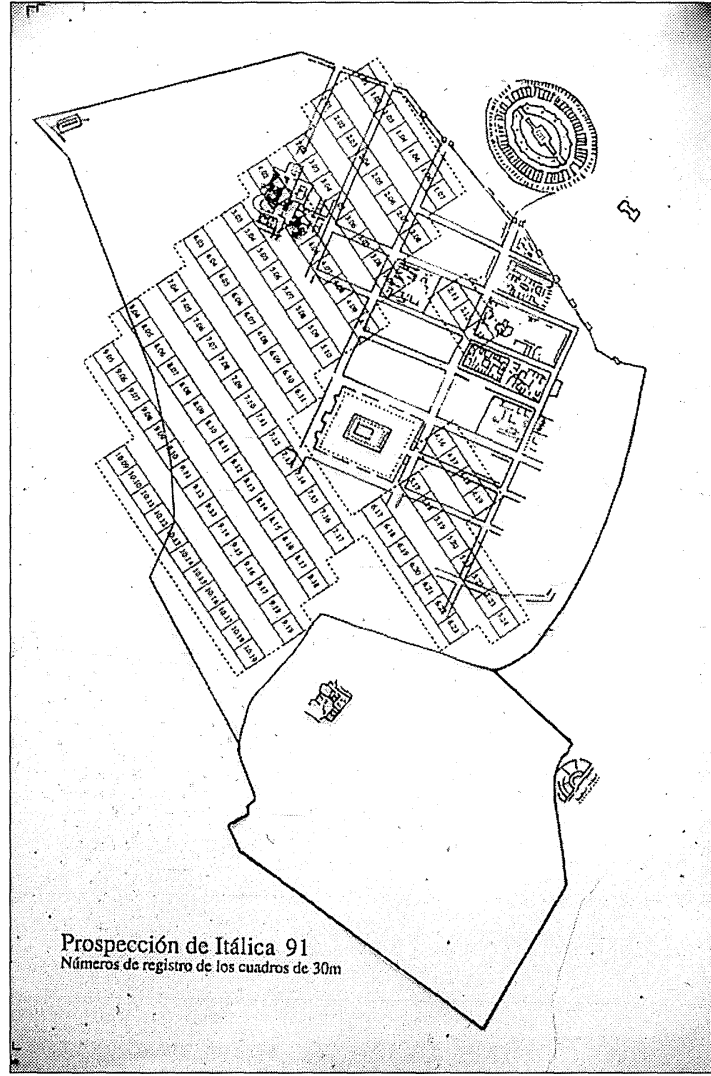

Fig. 8.-Localización y distribución de las cuadrículas de $30 \times 30 \mathrm{~m}$ para la prospección superficial.

estratigrafía que arranca en el siglo v a.C. (Pellicer, 1998). Este tipo de cerámica es pues muy abundante en Santiponce (Vetus Urbs), al igual que en otros muchos asentamientos del Bajo Guadalquivir. Esta ausencia notoria demuestra que, en esos momentos, lo que después fue la ampliación adrianea era terreno baldío o de pastoreo (figs. 8 y 9).

\subsection{Material Republicano}

En contraste con la única pieza de cerámica ibérica hallada, hay una mayor distribución de material republicano por el yacimiento, aunque tan solo se recogió $1,51 \mathrm{~kg}$ de materiales, el equivalente al $0,02 \%$ del material identificado. Las dos terceras partes de estas cerámicas correspondían a ánforas Itálicas (Dressel 1) y del Sur Peninsular (Haltern 70), mientras que el resto, en su mayor parte, eran fragmentos de Barniz Negro C. La localización de esta cerámica fina y de las ánforas era ligeramente diferente. Las primeras, en fragmentos bastante pequeños, se extendían por todas partes, mientras que

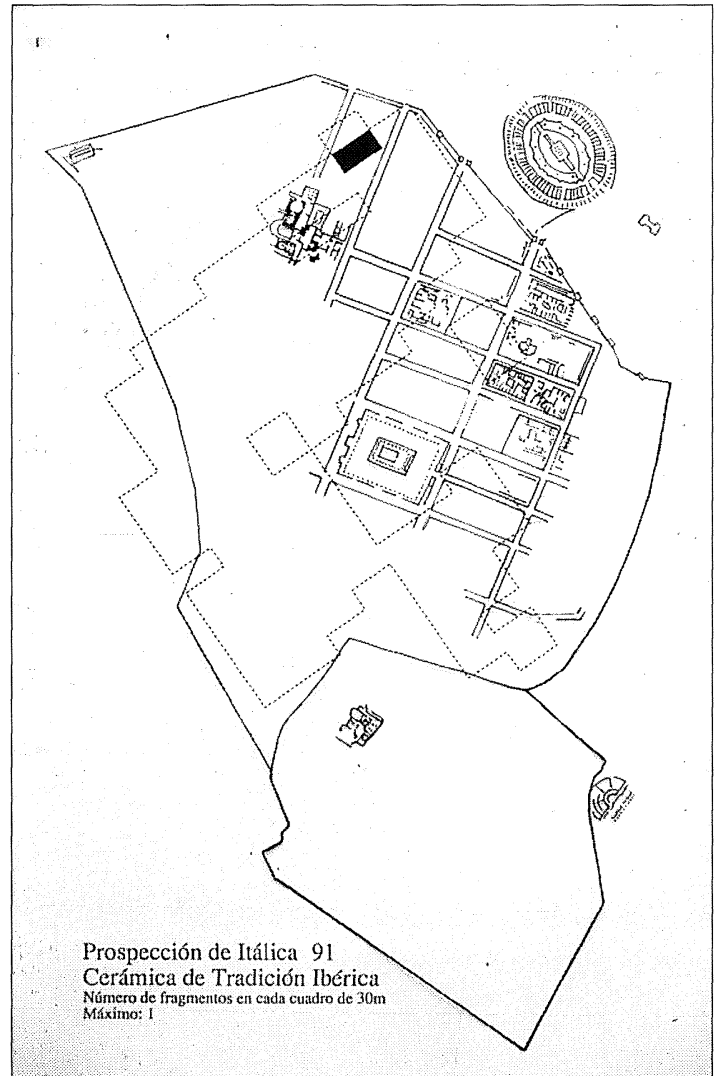

Fig. 9.-Localización y distribución de la cerámica de tradición ibérica.

las ánforas se agrupaban en el extremo suroccidental del área de estudio.

Al igual que ocurría con la cerámica ibérica, los escasos restos de cerámica republicana fina confirman que las dimensiones de la Itálica del momento no ocupaban nada del área que más tarde comprendió la Nova Urbs. Por el contrario, los fragmentos de ánforas se concentraban al oeste del lugar que posteriormente ocuparía el Traianeum. La prospección adicional efectuada en 1993 confirmó la continuación de estas ánforas republicanas más hacia el Oeste, asomándose casi hasta el arroyo del Cernícalo (figs. 10 y 11 ).

\subsection{Material Alto Imperial}

La mayoría del material de estudio identificable, el $83,85 \%$, era de cronología altoimperial; los mapas de densidad muestran su distribución por todo el área de estudio. Algo que no debe sorprender dado que, por consenso, el período adrianeo es el unánimemente aceptado para la construcción de la Nova Urbs. En un intento de comprobar esta hipótesis, la 


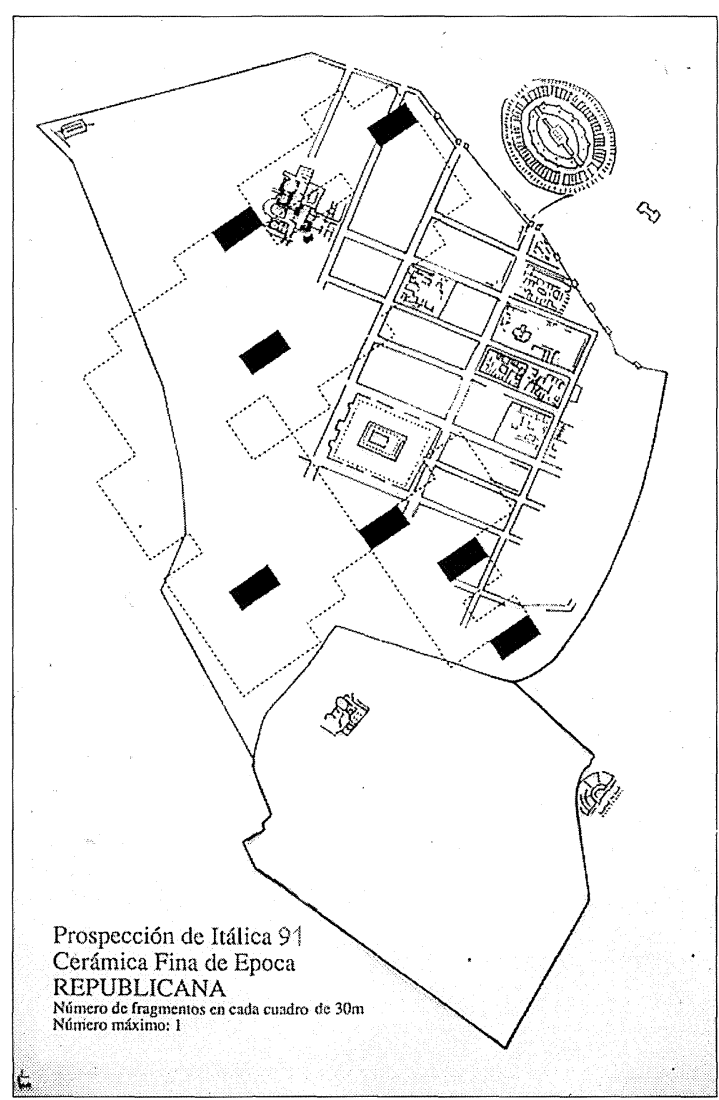

Fig. 10.- Localización y distribución de la cerámica fina de época republicana.

cerámica fina altoimperial fue analizada con detalle para ver si existía una cantidad significativa de material preadrianeo:

$\begin{array}{llll}\text { Terra Sigillata Clara A } & \text { Hayes 3a } & 60-90 \text { d.C. } & 3 \text { frags. } \\ \text { T.S. Clara } & \text { Hayes 3b } & 75-150 \text { d.C } & 5 \text { frags. } \\ \text { T.S. Clara A } & \text { Hayes } 8 \mathrm{a} & 80-160 \text { d.C. } & 2 \text { frags. } \\ \text { T.S. Clara A } & \begin{array}{l}\text { Hayes 5a, } \\ \text { 6a, } 20 \text { y }\end{array} & \text { pios S. II } & \\ & 21 \text { fines } & & 6 \text { frags. } \\ \text { T.S. Clara A } & \text { Hayes } & \text { Siglos I y II } & \\ & 191-192 & & 2 \text { frags. }\end{array}$

Los tres fragmentos Hayes 3a son la única evidencia preadrianea y en base a esa casi ausencia parece poco probable que hubiera actividad antes de la ejecución del proyecto adrianeo. Debería recordarse, no obstante, que las excavaciones de la «Casa de la Venus», en la parte Sur de la ampliación adrianea, en la zona más próxima a la Vetus Urbs, a escasos metros de su línea de muralla norte (Abad, 1982), produjeron evidencias de una posible ocupa-

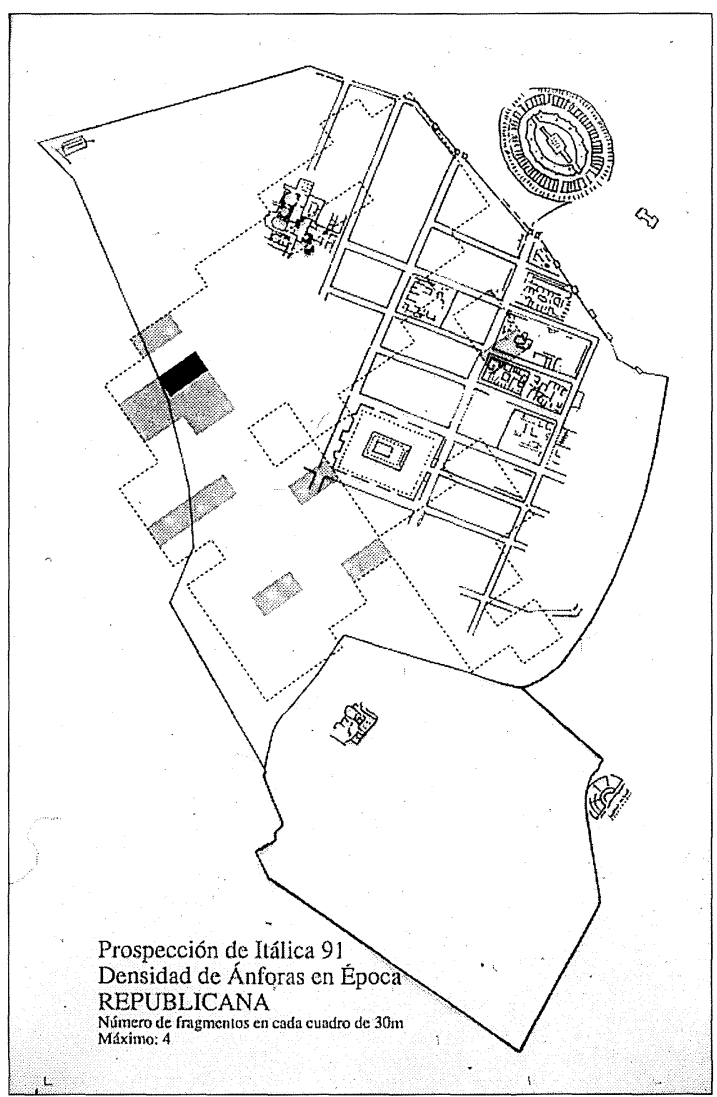

Fig. 11.-Localización y distribución de ánforas de época republicana.

ción preadrianea. El abanico de fechas de otras formas cerámicas empieza en época preadrianea y continúa a lo largo de todo el siglo II.

Una característica de la distribución de cerámica fina, común y ánforas por todo el yacimiento es la ausencia total en la gran zona rectangular descubierta por la geofísica al sur de las Termas Mayores. Esto enfatiza claramente el carácter público de la edificación, que se mantuvo limpio de añadidos inclușo después del abandono de gran parte de la Nova Urbs en el siglo III d.C.

En la distribución de materiales cerámicos existe un contraste entre la localización de las ánforas altoimperiales y el resto. Mientras los fragmentos de fina y común están distribuidos por todo el yacimiento, las ánforas tienden a concentrarse hacia el oeste del Traianeum, incluso fuera del recinto amurallado, coincidiendo, aunque en mayor cantidad lógicamente, con la localización de las ánforas republicanas y las lucernas. Esta concentración nos induce a pensar que nos encontramos sobre una zona de fabricación, almacenamiento o vertedero de estos contenedores, que habrá de ser analizada con mayor 


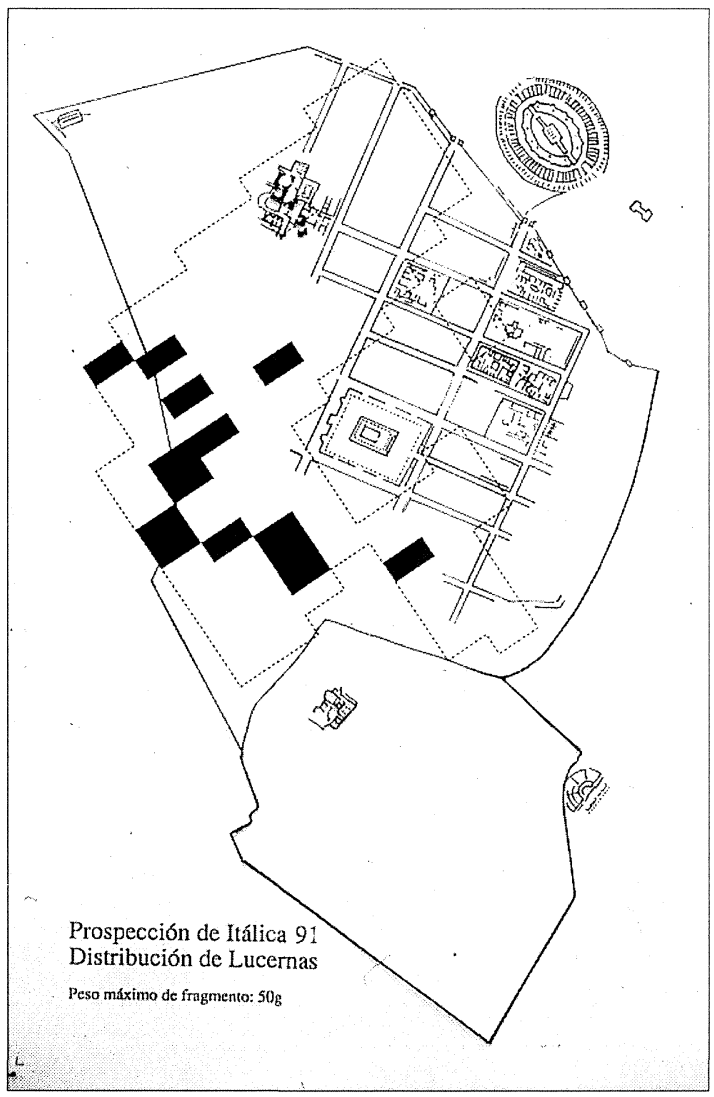

Fig. 12.-Localización y distribución de lucernas. Todas las épocas.

detenimiento cuando se efectuen excavaciones. Es de interés recordar aquí que en las excavaciones efectuadas en 1978 y 1979 por M. Pellicer en las murallas y castellum aquae, a unos $50 \mathrm{~m}$ al sur de éste se descubrió un depósito de ánforas tipo Beltrán II-B, correspondientes a la primera mitad del siglo II (Pellicer, 1982. Figs. 12, 13, 14 y 15).

\subsection{Material Tardo Imperial}

Las cerámicas tardoimperiales recolectadas constituyen el $13,27 \%$ del material clasificado en todo el estudio. La mayoría, $5,405 \mathrm{~kg}$ pertenecían a piezas fácilmente identificables, especialmente T.S. Clara C y D, mientras que las ánforas, especialmente de origen norteafricano, tan solo sumaron $1,560 \mathrm{~kg}$.

Al igual que con la cerámica altoimperial, se procedió a establecer los mapas de distribución y concentración de las cerámicas finas, común y ánforas. En gran parte la concentración se restringió a la vertiente sur de la Nova Urbs, junto al Traianeum

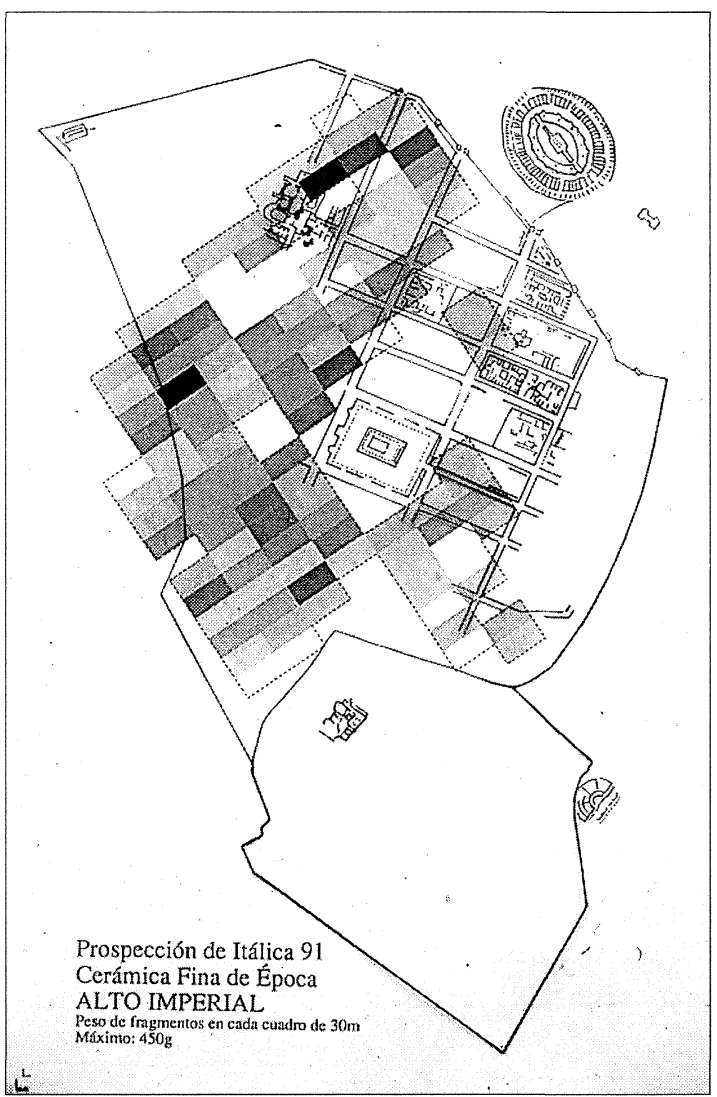

Fig. 13.-Localización y distribución de cerámica fina de época alto imperial.

y sus inmediaciones, dentro de la muralla $\mathrm{C}$ descubierta por la geofísica. Tan solo una cantidad insignificante se localizó sobre la vertiente norte de la Nova Urbs.

Las imágenes reveladas por la geofísica nos muestran que la zona urbana inscrita en la muralla $\mathrm{C}$ se caracteriza por una larga secuencia de construcciones, reconstrucciones y reformas en las distintas piezas urbanas, que se presentan muy complejas y alteradas respecto a la vertiente norte, fuera de esa muralla. Esta secuencia ya fue analizada en la excavación de la «Casa de Venus» (Abad, 1982) y en el estudio de las monedas procedentes del Traianeum (Chaves, 1988). Parece, por tanto, que la distribución de la T.S. Clara C y D refleja una contracción substancial del área urbana de la Itálica de Adriano ya en época romana. La fecha y distribución de las cerámicas finas sugieren que este complejo proceso empezó a tener lugar, probablemente, durante el siglo III d.C., puesto que la T.S. Clara $\mathrm{C}$ de principios del siglo III d.C. tiene una distribución más amplia que la de finales del siglo. De este análisis también parece desprenderse que no 


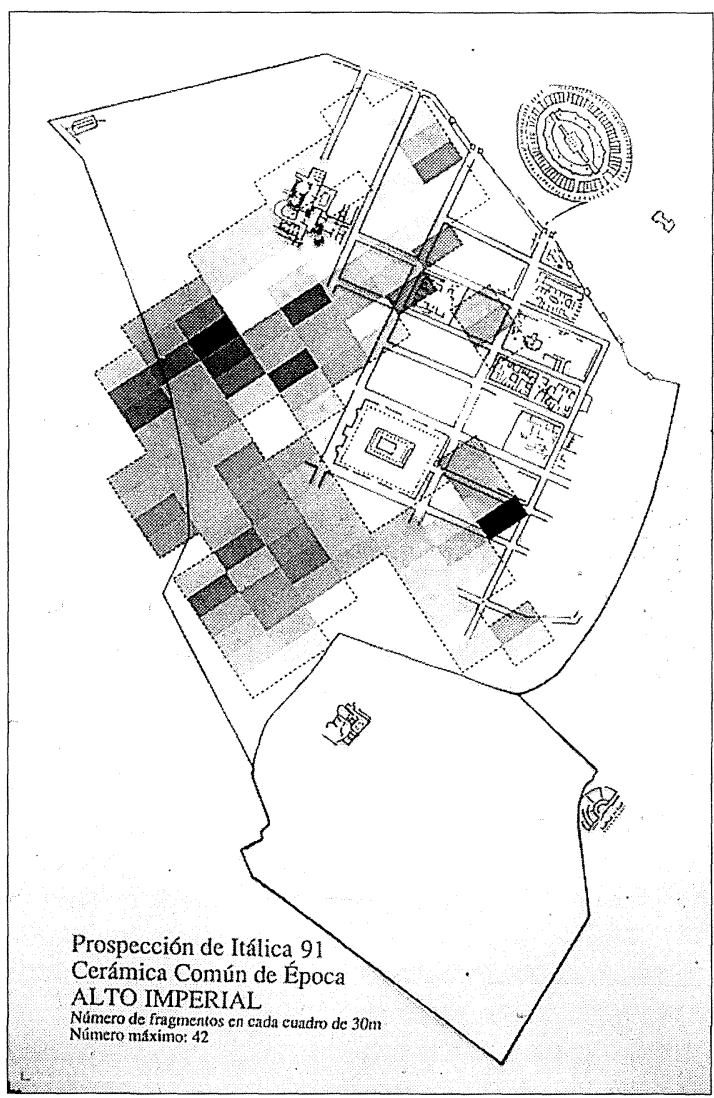

Fig. 14.-Localización y distribución de cerámica común de época alto imperial.

existieron regresiones urbanas durante los siglo IV, $\mathrm{V}$ y vi d.C.

La distribución de las ánforas tardías era muy diferente. La mayoría de los fragmentos se localizaron, una vez más, fuera de la muralla $\mathrm{C}$, donde desde época republicana venían concentrándose los restos de estos contenedores (figs. 16 y 17).

\subsection{Material de construcción}

El análisis de la distribución de las distintas clases de materiales de construcción presentó varios problemas. El principal fue que muy pocos pudieron ser adscritos cronológicamente y por ello el estudio de distribución, al menos en lo que respecta a las cronologías, no aportó nada al estudio general, ya que por todo el yacimiento se localizaron restos de estucos, fragmentos de opus signinum, teselas o mármol. El estuco se localizó, con pocas variaciones, a lo largo de todo el área de estudio. Sí había diferencias en la distribución del opus signinum y de las teselas, más común el primero en

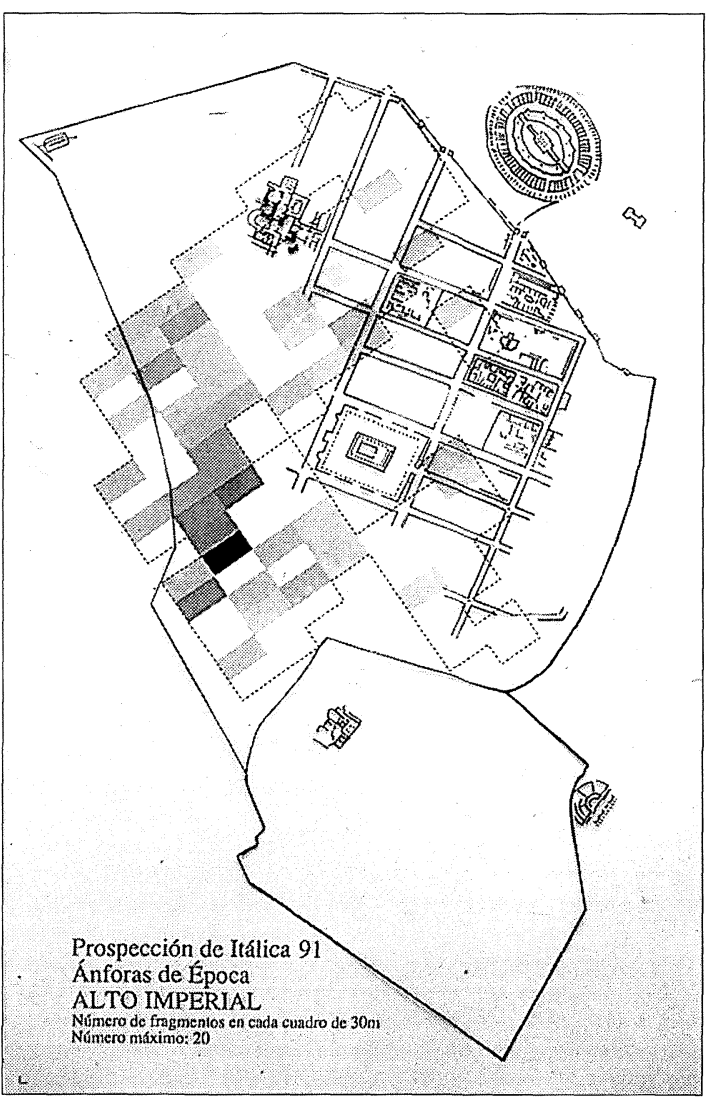

Fig. 15.-Localización y distribución de ánforas de época alto imperial.

las proximidades de las Termas Mayores, también en el edificio J y en el K. El significado no está claro, aunque es lógico pensar en los pavimentos de opus signinum para las mayores superficies de los edificios públicos, frente al opus tesellatum, más propio de las casas, aunque en las Termas Mayores exista uno de teselas más largas que las domésticas, que fueron las localizadas durante las recolecciones.

También los mármoles se localizaron por todo el yacimiento, aunque las mayores concentraciones se produjeron, obviamente, junto a los edificios públicos, Traianeum, Termas Mayores y Edificio $\mathrm{K}$, decorados con ricos mármoles y donde también en época moderna se construyeron hornos, a pie de cantera, para fabricar cal a base de los abundantes y ricos ornamentos marmóreos (figs. 18, 19 y 20).

El análisis de los mármoles coloreados, efectuado por I. Rodá, muestra que estos edificios públicos estaban decorados con mármoles procedentes de las canteras imperiales de todo el Mediterráneo, además de otros procedentes de la Bética: Macael, Alconera y Almadén de la Plata. 


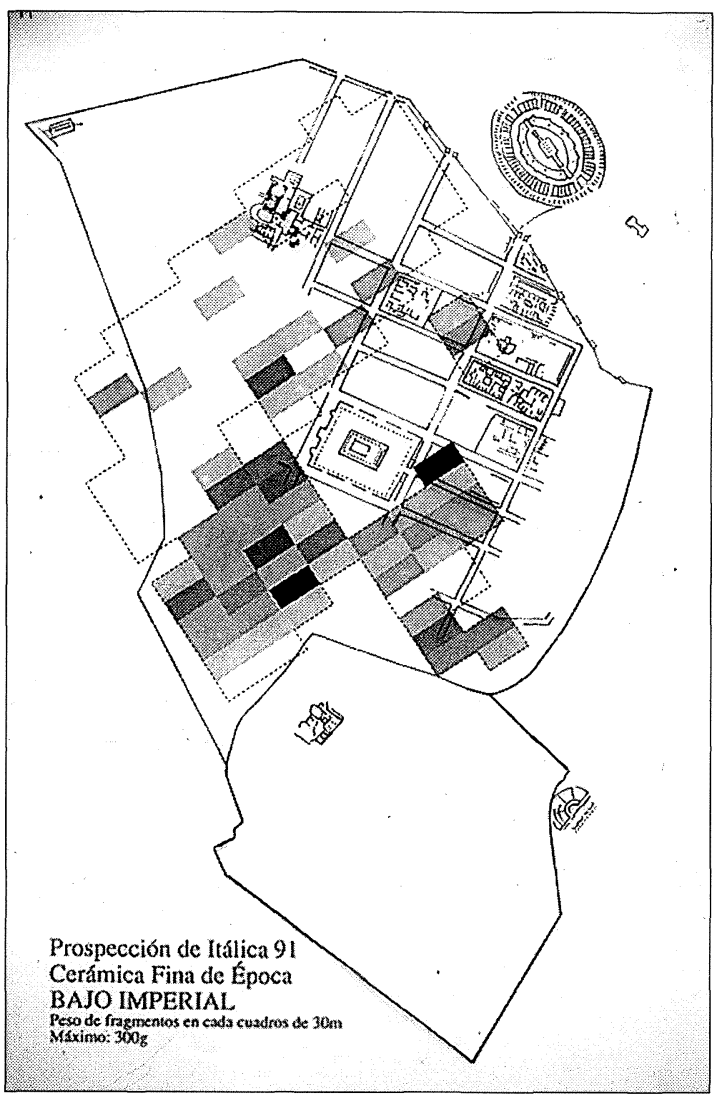

Fig. 16.-Localización y distribución de cerámica fina de época bajo imperial.

\section{ANÁLISIS E INTERPRETACIÓN DE LOS RE- SULTADOS}

No cabe duda de que los resultados de la geofísica, sumados a los de la recolección sistemática de materiales de superficie, como se ha tenido ocasión de comprobar, han sido realmente generosos, ya que han dado respuesta a todos los interrogantes previos a la ejecución del proyecto, posibilitando a su vez la contemplación de la imagen real del proyecto emblemático de Adriano, además de proporcionarnos una idea acerca de su construcción, transformación y abandono. Frente a las respuestas, la contemplación de esa imagen real genera nuevas hipótesis y abre otras posibles líneas de investigación cuya articulación física y cronológica podemos establecer en la potente muralla tardoimperial, que altera el proyecto original, en cuyo interior la geofísica presenta una imagen comprimida, de estructuras superpuestas, que resultan complejas y difíciles de interpretar y donde trabajos anteriores revelaron una amplia secuencia estratigráfica (Abad, 1982).

La recolección superficial, por su parte, ha ratifi-

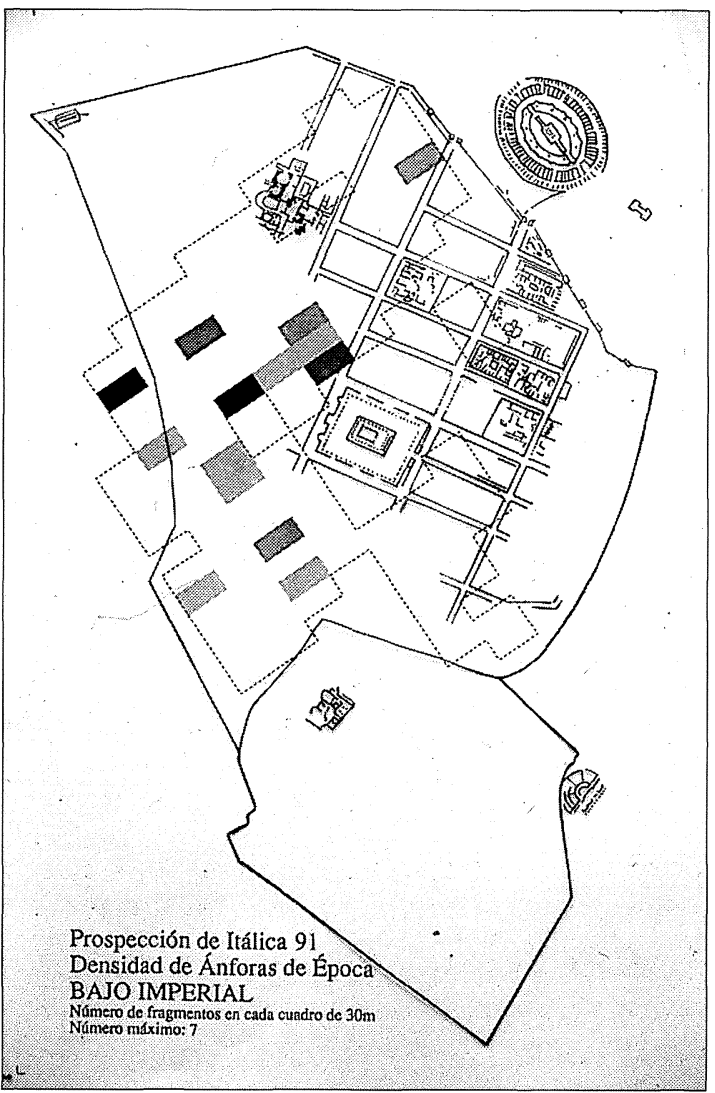

Fig. 17.-Localización y distribución de ánforas de época bajo imperial.

cado que la Nova Urbs fue una creación de Adriano, que fue abandonándose en el transcurso del siglo III, reduciendo sus dimensiones con la construcción a finales del siglo III-principios del IV de una nueva y potente muralla donde la ocupación fue continua al menos hasta el siglo v (figs. 21 y 22). La nueva imagen de la Itálica de Adriano, como máximo exponente de su descripción, así como su análisis e interpretación, nos permite abordar una serie de conclusiones definitivas sobre la evolución y articulación entre la Itálica preadrianea, la expansión adrianea y la postadrianea. Con todos los datos obtenidos podemos afirmar que la ampliación de Adriano ocupó una superficie de $38 \mathrm{Ha}$. El entramado ortogonal de ésta lo contituyen unos $7.090 \mathrm{~m}$ de viario, que articulan un total de cuarenta y ocho insulae, más seis espacios residuales de planta triangular o trapezoidal. Entre las insulae, de superficies varias, cinco albergan a otros tantos edificios públicos, a los que habrá que añadir el Anfiteatro, el castellum aquae y el tetrapilon (León, 1988). Otras treinta y nueve insulae tienen uso doméstico y acogen un total de cuarenta y ocho domus de superficie igualmente varia, 


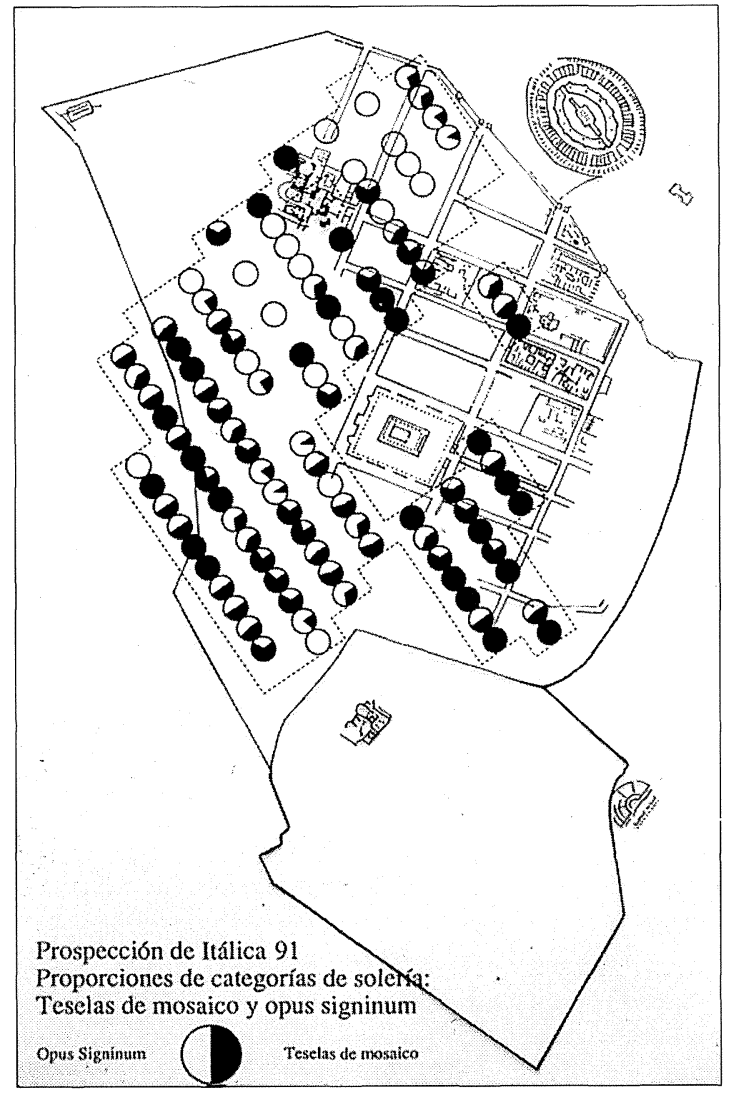

Fig. 18.-Localización y distribución de restos de pavimentos de opus signinum y teselas.

oscilando entre unos $1.800 \mathrm{~m}^{2}$ de la «Casa de los Pájaros», unos $4.300 \mathrm{~m}^{2}$ de la «Casa de David» y los más de $6.000 \mathrm{~m}^{2}$ de la «Casa de Neptuno». En otras dos insulae se ubican edificios de carácter semipúblico; se trata de las hasta ahora denominadas «Casa de Neptuno» y «Casa de la Exedra», cuyo análisis constructivo y espacial, pese a su estructura doméstica, ha llevado a identificarlas como posible sede de algún collegium o schola (Rodríguez Hidalgo, 1991). Esta hipótesis, que habrá que corroborar con nuevas excavaciones, nos induce a pensar que entre las domus aún por excavar pueden existir otros edificios de semejantes características y usos.

A las dos insulae restantes, situadas al sur de la ampliación adrianea, paralela al arroyo del Cernícalo y con la misma orientación que el Anfiteatro, tras el análisis de la distribución de las ánforas le otorgamos, como hipótesis, un uso artesanal. Se trataría de una zona de almacenamiento, manipulación o producción alfarera (especialmente de ánforas y lucernas) existente en el lugar desde época republicana, absorbida por la expansión adrianea, lo que justificaría el cambio de orientación respecto a la trama ur-

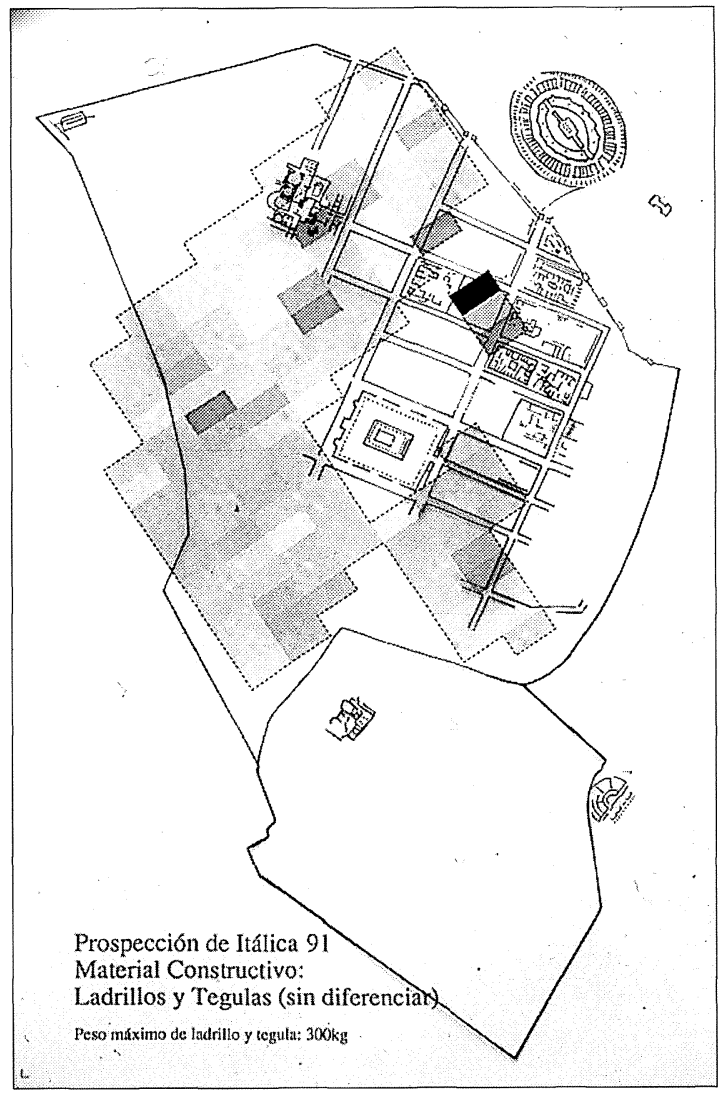

Fig. 19.-Localización y distribución de ladrillos y tegulae.

bana. Se trataría pues de algo preexistente, transformado y encajado dentro del proyecto de Adriano.

La prospección geofísica también ha permitido lả localización de dos nuevos edificios públicos y el desarrollo completo del conjunto termal. Situado sobre el vértice noreste de éste se aprecian los restos de un edificio (D2-D3) que ocupa una insula cuadrada. Está bastante destruido y no nos aventuramos a otorgarle un uso concreto, tan sólo afirmar que se trata de un edificio público de carácter civil, tal vez un macellum del que afloran en superficie algunas cimentaciones de opus caementicium.

La definición del conjunto termal constituye una de las grandes aportaciones individuales de la geofísica. Las hasta ahora Termas Mayores o Baños de la Reina Mora se han manifestado como un complejo constructivo de enormes dimensiones, cuya superficie total supera los $32.000 \mathrm{~m}^{2}$. Muy en la línea helenística, está constituido por las termas propiamente dichas (decoradas por una serie de mármoles importados, según resultados del análisis de los mármoles recuperados en la prospección superficial), a las que se le adosa una gran palestra (I) de 


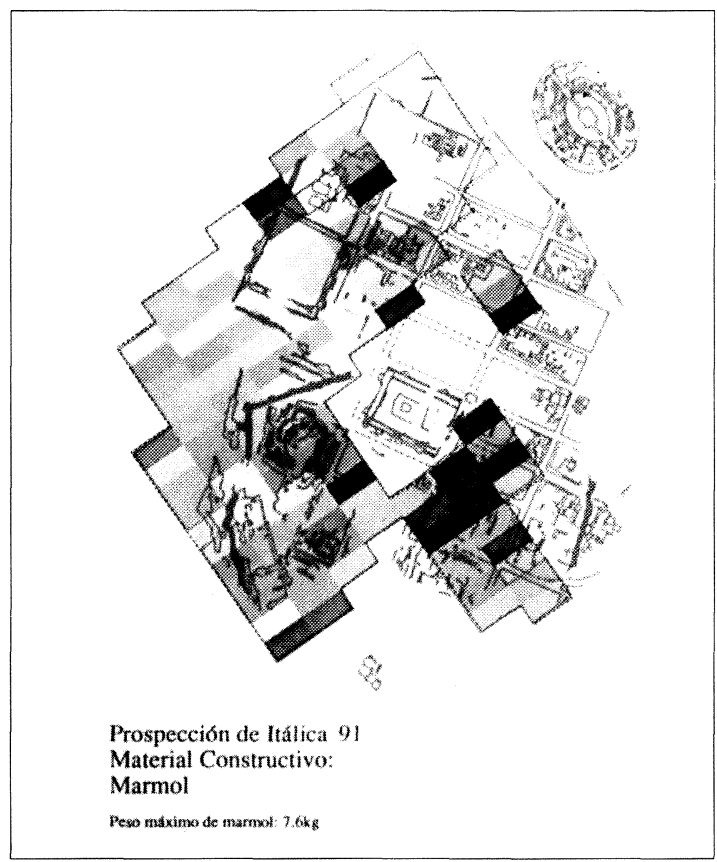

Fig. 20.-Localización y distribución de los mármoles.

planta similar al Traianeum. Posiblemente, dadas sus dimensiones, para ejercicios ecuestres y, quizá, cerrando por el sur, una schola. Los paralelos para

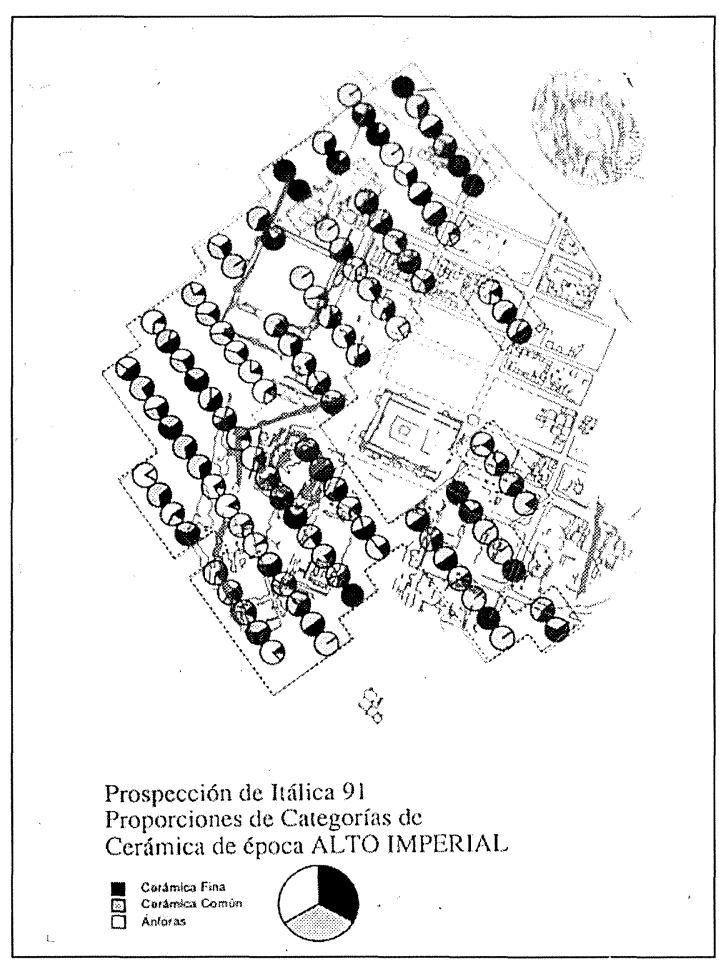

este complejo los encontramos en el Gimnasio Helenístico y Termas de Cneo Vergilio Capito (Mileto); también en Éfeso, en el Gimnasio de Vedio o en la planta del Gimnasio del Puerto y en el Gimnasio del Teatro (Gros, 1996, pp. 413-415; Nielson, 1990, figs. 219 y 226). Sin duda alguna, hoy por hoy constituyen el complejo termal más grande de Hispania. La alternancia de ábsides semicirculares y cuadrangulares en el muro de fachada del gimnasio lo asemeja con la planta del Traianeum, sugiriendo una iniciativa y diseño común.

Al margen de la muralla tardía, el tercer edificio público $(\mathrm{K})$ revelado por la geofísica tiene un uso civil. Situado al suroeste del Traianeum, se trata de otra gran edificación, de aproximadamente 15.000 $\mathrm{m}^{2}$, constituida por un núcleo de planta cuadrangular en el que se inserta un semielipse que sobresale por la trasera a modo de gran ábside. Más al sur y formando parte de la edificación tenemos una serie de construcciones que se le adosan, constituyendo, al parecer, un complejo único.

Durante las excavaciones del Traianeum, P. León efectuó un sondeo sobre este edificio descubierto ahora por la geofísica. Exhumó temporalmente parte de un hypocaustum y suspensurae, lo que denota un uso termal, al menos parcialmente en algún estadio de su vida. Este dato, al margen de la planta, de

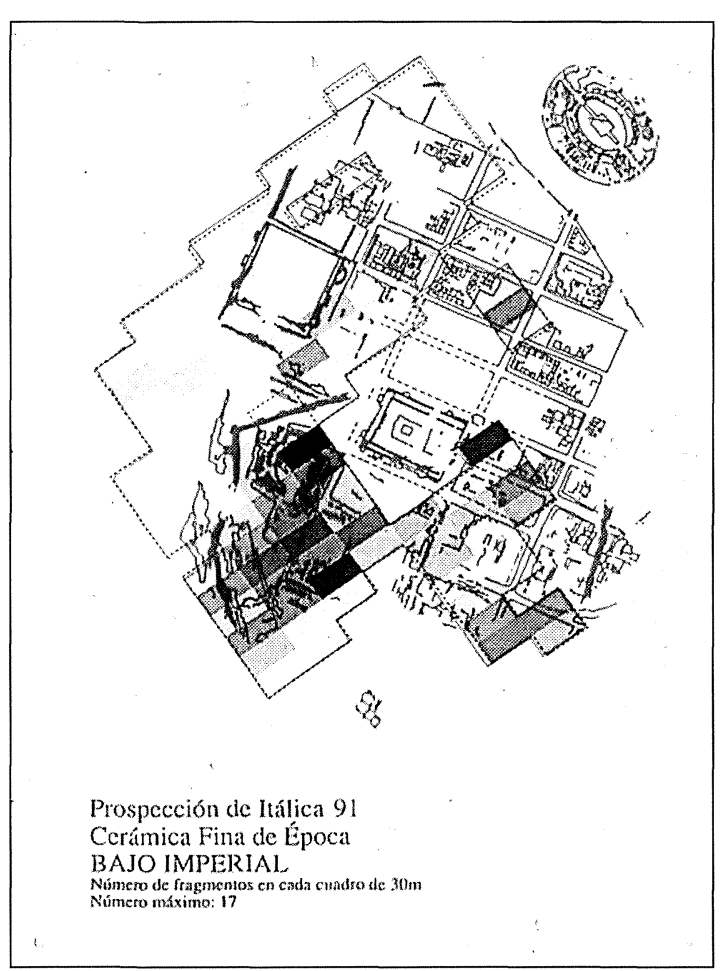

Figs. 21 y 22.-Un estadio más avanzado del trabajo permitió superponer a los resultados geofísicos la distribución de los materiales recogidos en superficie. 


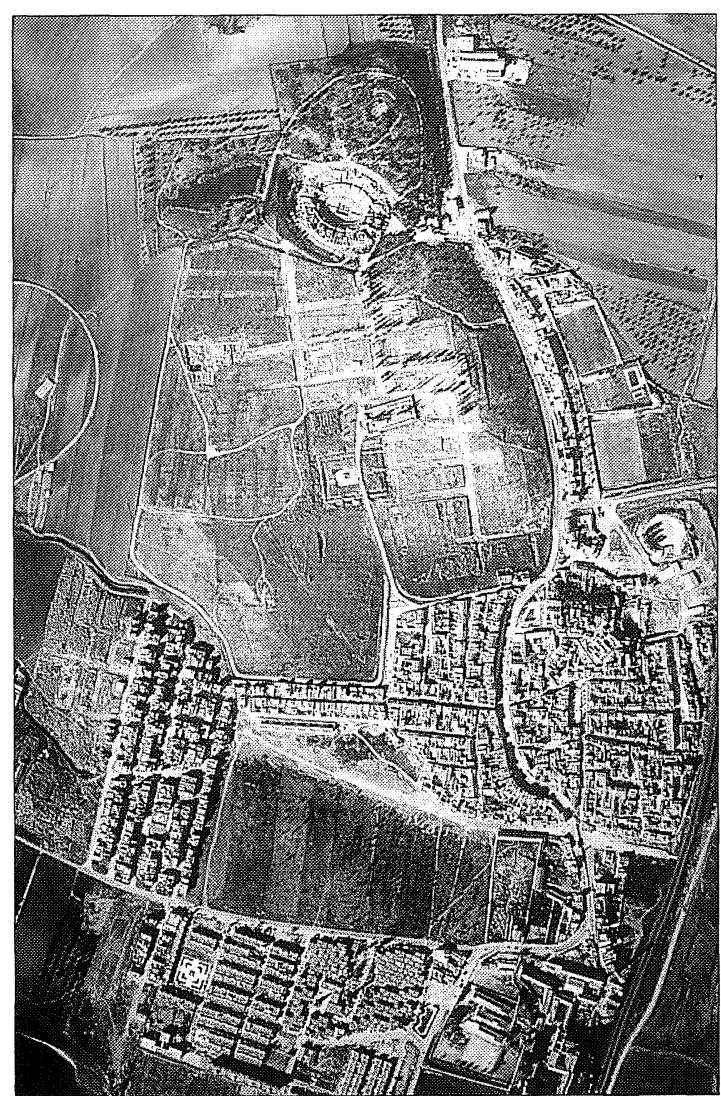

Fig. 23.-Vuelo fotogramétrico vertical, enero de 1991, previo al desarrollo del trabajo.

difícil lectura, ya que la potencia de los derrumbes constructivos han comprometido la claridad de los resultados de la geofísica, es el único elemento objetivo que poseemos sobre este edificio público. La topografía y la forma semielíptica sugieren, como hipótesis, que se trate de un edificio con graderío: teatro, odeón. De ser cierto, tendríamos que pensar en una transformación en termas durante el Bajo Imperio, algo que nos parece poco probable teniendo en cuenta la evolución sufrida por la ciudad. Otra hipótesis, por la que nos inclinamos, es pensar en un edificio residencial de carácter palaciego. Sus formas y, quizás, también sus posibles usos recuerdan a algunas construcciones de la Villa Hadriana; al propio Teatro Marítimo con su núcleo residencial, la Sala de los Filósofos o la Academia (Ward-Perkins, 1972). De cualquier manera, a diferencia del complejo termal, habrá que recurrir a la excavación para otorgarle la funcionalidad adecuada.

A pesar de los resultados, existen algunos interrogantes por resolver. Por ejemplo, queda por confirmar el grado de ocupación de todas las insulae que constituyen el entramado urbano. Concretar si

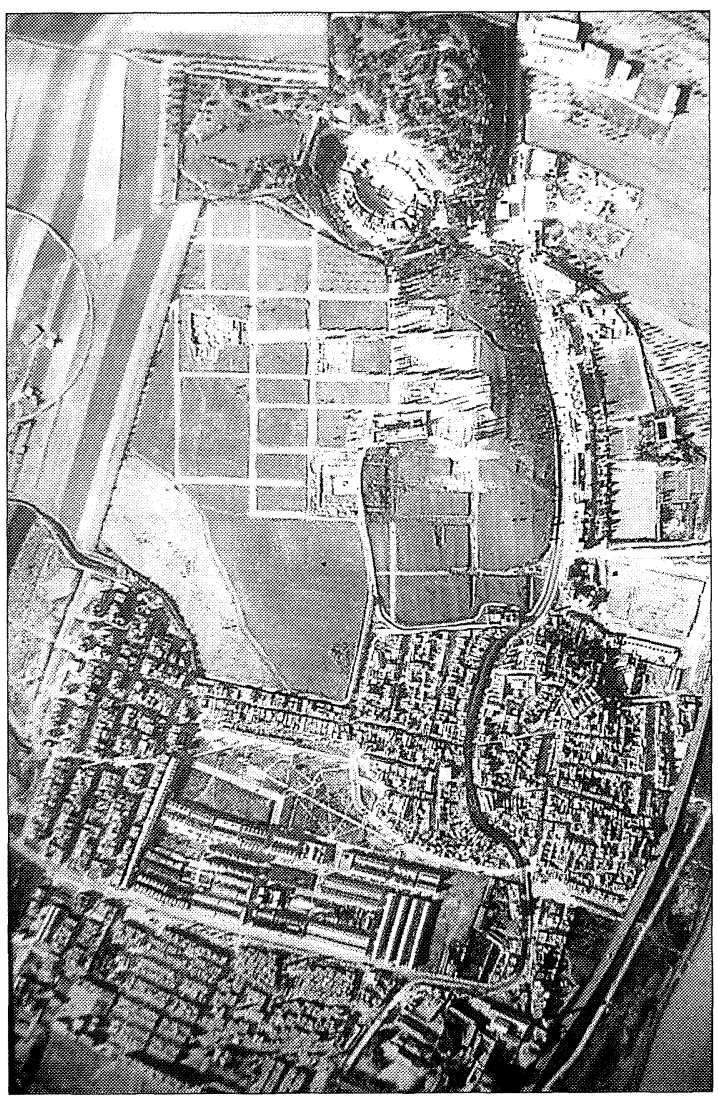

Fig. 24.-Vuelo fotogramétrico vertical, diciembre de 1996, en el que se aprecia la transformación del yacimiento basada en los resultados del trabajo.

el cien por cien de lo urbanizado fue edificado y ocupado. La acción antrópica puede ser la causa que justifique la carencia de información en las cuatro insulae al Norte del complejo termal (D-D-D1), aquellas en las que la geofísica simplemente documenta el trazado de la red de cloacas. Saber si no se edificaron o si fueron destruidas durante la explotación del yacimiento como cantera es una de las incógnitas que tendrá que resolver la excavación de campo o la revisión de los resultados de la geofísica. Estos mismos enigmas se reservan para la franja de terreno existente entre el complejo termal y el castellum aquae. Aquí, las prospecciones geofísicas efectuadas en abril de 1993 sólo constataron la existencia de una conexión entre el castellum aquae y las termas, como primer receptor físico del agua pública. En nuestra opinión ambas zonas, pese a la ejecución de la infraestructura de cloacas, jamás llegaron a edificarse. Ya a raíz de las excavaciones efectuadas en 1978 y 1979, Pellicer se aventuró a afirmar que las zonas norte y sur de las Termas Mayores se urbanizaron, aunque no se edificaron las insulae, y que la franja de terreno existente al oeste 


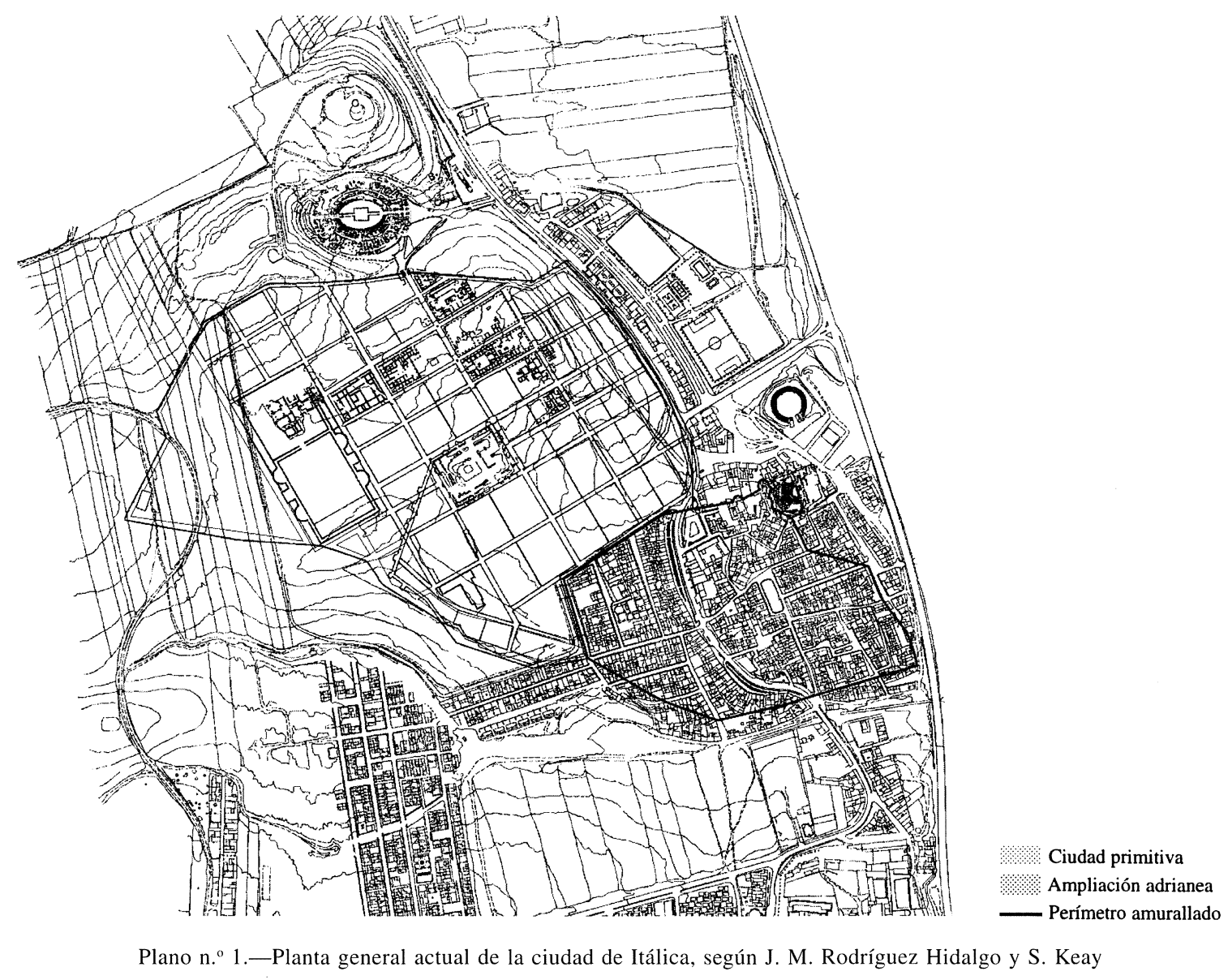

de las Termas, entre éstas y el castellum aquae, no llegó ni siquiera a urbanizarse (Pellicer 1982). Ahora, gracias a la geofísica, se puede matizar esta generalización, ya que las insulae han sido realmente dimensionadas, constatándose además la existencia de un edificio público (D2-3) en una insula descartada de antemano por él, al noroeste de las Termas y al sur de las mismas, donde se ha localizado la Palestra del Gimnasio. Se puede concretar entonces que la zona urbanizada y no edificada se limitaba solamente a las cuatro insulae existentes al norte de las Termas Mayores, manteniéndose la afirmación de no urbanización para la zona existente entre éstas y el castellum aquae.

Los resultados de este proyecto de investigación y su aportación al conocimiento de la Itálica de Adriano vienen a avalar la excepcionalidad, al menos arqueológica, de lo auspiciado por el Emperador. Algo que podemos definir como una urbanización, un barrio de prestigio, donde destaca el carácter residencial conformado por la abundancia de domus de grandes dimensiones. Con ellas los edificios semipúblicos, sedes de asociaciones y los dedicados al ocio y a la diversión. Todo ello presidido física y espiritualmente por el Traianeum, donde se rendía culto al Divus Traianus, a la Familia Imperial y al Imperio (León, 1988). Junto a él, en el ángulo noreste, el tetrapilon que, a modo de groma, enfatiza el corazón físico e ideológico del proyecto urbanístico (Rodríguez Hidalgo, 1987-88).

Los paralelos de casi todos los edificios públicos identificables se encuentran en la parte oriental del Imperio, donde se hablaba griego. Las similitudes entre el Conjunto Termal y el Gimnasio de Itálica y edificios de Éfeso se han mencionado con anterioridad. No obstante, el Traianeum proporciona el ejemplo más claro y evidente. El cierre del templo dentro de un embellecido temenos poblado de estatuas de personajes ilustres (León, 1988) encuentra su reflejo inmediato en la Nueva Atenas de Adriano, en la Biblioteca de Adriano (Travlos, 1980, 242-52), en el llamado Panhellenion de Hera y Zeus (Travlos, 429-431) e incluso en el Olympeion (Travlos, 402-411). Similitudes que han llevado a M. Boa- 


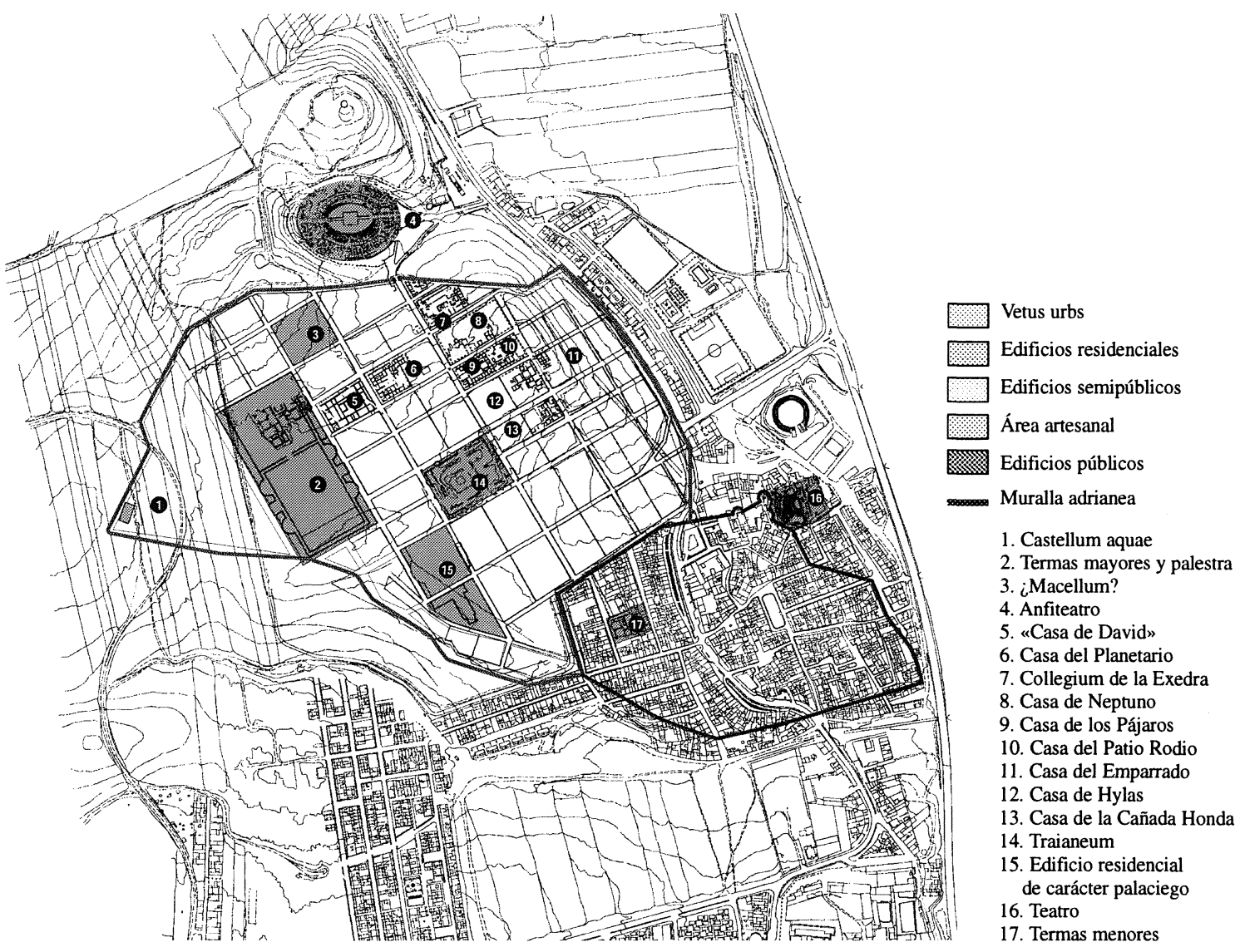

Plano n. ${ }^{\circ}$ 2.-Planta general de Itálica (J. M. Rodríguez Hidalgo y S. Keay)

trwright a reconocer la presencia directa e implicación de Adriano en el nuevo proyecto italicense (Boatwright, 1997).

Con las evidencias proporcionadas por nuestro estudio y los otros datos referenciados sería perverso negar la mano de Adriano en el nuevo proyecto urbanístico de Itálica. Algo que ya resaltó Dion Casio cuando se refería a los «múltiples» y «espléndidos» regalos que Adriano, además del estatuto de colonia, concedió a Itálica: Colonia Aelia Augusta Italicensium. Pero la acción de lo adrianeo es también rastreable en puntos de la primitiva Itálica, donde se documentan reedificaciones, transformaciones y embellecimientos varios. Perfectamente documentados en el Teatro y en especial en el gran complejo que se proyecta sobre su summa cavea, allí donde en 1900 se encontró la estatua de Diana Cazadora en el interior de una capilla y donde con anterioridad y posterioridad se localizaron las de Mercurio y Venus, respectivamente. Todas ellas exponentes de la también excepcionalidad escultórica de Itálica en época de Adriano (Rodríguez Hidalgo y Keay, 1995).
De todos es bien conocido el interés del Emperador por la cultura griega y, reconociendo el helenismo de su proyecto en Itálica, podríamos preguntarnos si esa obra no fue un intento de promocionar lo griego en su provincia de origen. En cualquier caso podemos enfatizar la excepcionalidad del proyecto adrianeo, no sólo en la Baetica o Hispania, sino también en el Occidente del Imperio. La Itálica de Adriano supone pues un intento de trasmutar el Oriente en Occidente, desde donde se importaron modelos y proyectos, además de materias primas y mano de obra especializada para su manufacturación. A falta de los «pormenores del detalle», nuestra comprensión es ahora muy completa, hasta el punto de poder afirmar que la Itálica de Adriano es uno de los más claros y mejor conocidos ejemplos de las ideas arquitectónicas y urbanísticas del Emperador.

El análisis e interpretación de todos los datos obtenidos en la investigación nos ha permitido conocer la evolución de la transformación urbanística de Itálica. Con un perímetro amurallado de unos $1.520 \mathrm{~m}$ y una superficie próxima a las $13,5 \mathrm{Ha}$, la primitiva Itálica ve cómo el proyecto de Adriano 


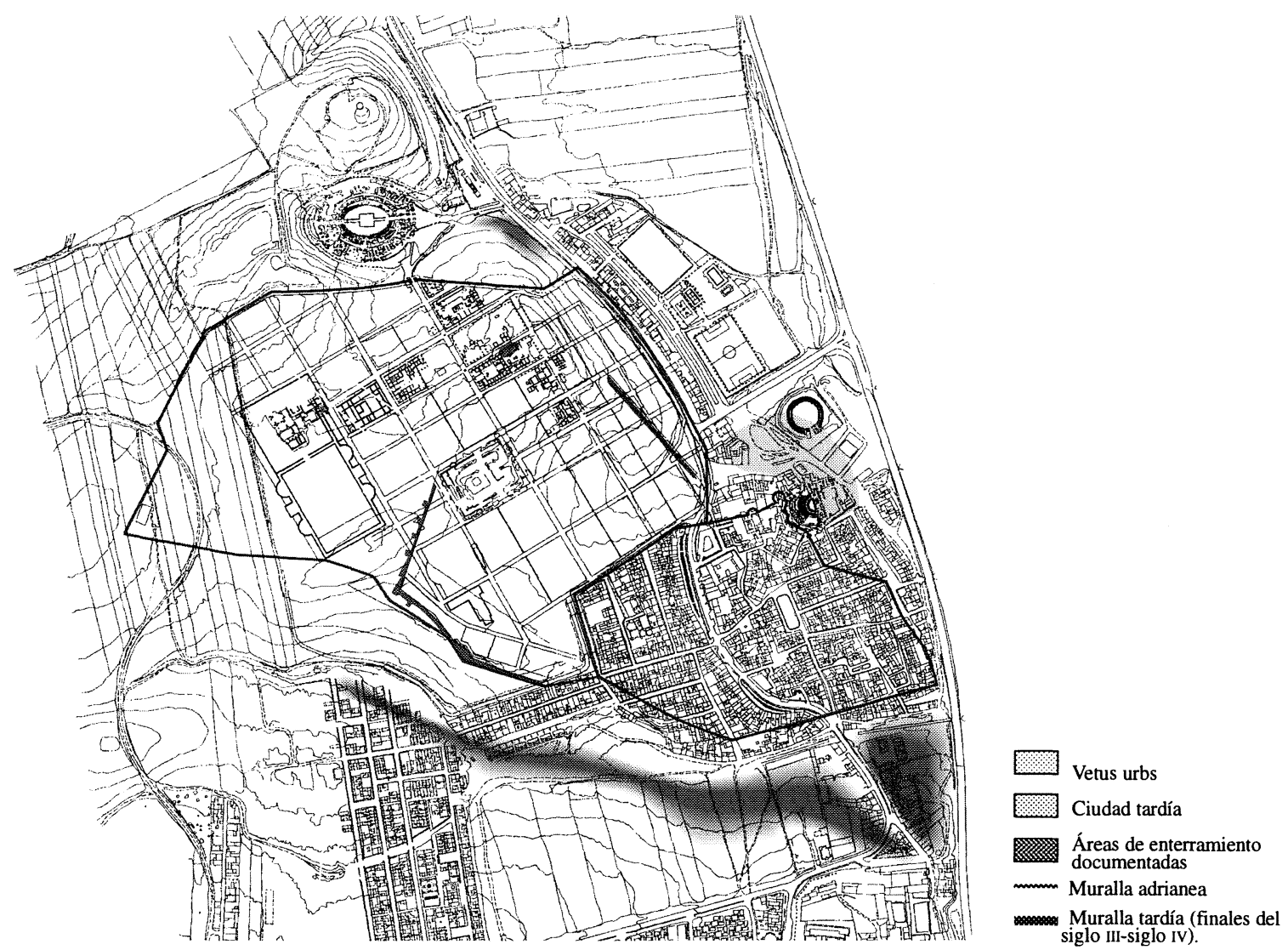

Plano n. 3.-Planta de la situación de Itálica en época bajo imperial, según J. M. Rodríguez Hidalgo y S. Keay.

amplía sus murallas con otros $2.460 \mathrm{~m}$, que abarcan una superficie de algo más de $38 \mathrm{Ha}$; es decir, que Itálica en época de Adriano ocupa una superficie total de 51,1 Ha aproximadamente. A mediados del siglo III se produce el abandono del proyecto adrianeo. A fines de ese mismo siglo o principios del IV, con la construcción de una nueva y potente muralla, que en la parte oriental del yacimiento atraviesa y secciona varias domus, se materializa la «colonización» por los italicenses de 13,3 Ha del abandonado proyecto urbanístico de Adriano. Esta nueva etapa, en la que Itálica ocupa $26,9 \mathrm{Ha}$, perdurará con evidencias hasta por lo menos los finales del siglo vi, dado que se conoce que el rey Leovigildo reconstruyó las murallas de Itálica en el 584 en el contexto de sus campañas contra Hermenegildo (Juan Biclarense, Chron., A.584.1). A partir de esa fecha muy poco es lo que sabemos de Itálica, que siguió estando históricamente presente a través de sus obispos, delegados en varios concilios hispanos desde el año 589 al 639. Grosso modo éste es el proceso de evolución urbanística sufrido por Itálica desde su fundación en el año 206 a.C. hasta la inva- sión musulmana y, con ella, su transformación en Campos de Talca o Tálica.

En los resultados de la geofísica hemos podido observar cómo todo lo que aparece al norte del Traianeum, fuera de la muralla tardía, excavado o prospectado, presenta una imagen de gran nitidez. Intramuros, por el contrario, salvo los edificios públicos (Traianeum y edificio K) y el viario, todo es confuso y difícil de interpretar. Ello es debido al proceso de «colonización» referido con anterioridad, cuando las domus adrianeas se transforman, pasando ahora de ser grandes mansiones a viviendas plurifamiliares, con más de cinco siglos de ocupación y alteración de las estructuras iniciales.

El no haber localizado el límite norte de la muralla tardía nos induce a pensar que el propio muro de cierre norte del Traianeum pudo desempeñar también funciones defensivas desde fines del siglo III-IV. Fuera de la muralla tardorromana, al noroeste del Traianeum, en la denominada Casa de Hylas, se localizaron en 1987, y aún permanecen sin excavar, dos enterramientos tardoimperiales, algo que confirma y ratifica el abandono de la Itálica de Adriano. Como 
ha podido constatarse, el análisis evolutivo de la ciudad se ha articulado en torno a los muros defensivos, obviándose pues las áreas suburbanas surgidas en sus alrededores y las necrópolis, que por cuestiones técnicas quedaban fuera de nuestro ámbito de trabajo.

Con los resultados de nuestro estudio se ha dado respuesta a múltiples interrogantes, corroborado y desechado hipótesis. Hemos podido ver la imagen física de la Itálica de Adriano y comprendido sus construcciones y transformaciones urbanísticas. Ello nos plantea nuevas incógnitas y sugiere nuevos proyectos de futuro. Desde nuestra opinión, saber porqué no se edificó la zona norte y oeste del Conjunto Termal, cómo se resolvió la zona de contacto entre la primitiva Itálica y la ampliación de Adriano, así como toda la transformación tardoimperial, son las grandes incógnitas que ha de resolver la investigación arqueológica en Itálica. Al margen de los resultados, para nosotros el éxito ha estado en la elección y aplicación de un método no destructivo que nos ha permitido el conocimiento global del yacimiento.
Con la experiencia de este estudio podemos afirmar que la combinación de las dos técnicas de prospección, superficial y geofísica, se manifiesta como un método útil y rápido para la comprensión de los grandes yacimientos urbanos que en la actualidad tienen un carácter rural o agrícola, aislado y fuera de las aglomeraciones urbanas modernas, donde el carácter superpuesto de algunas ciudades dificulta e imposibilita la aplicación de esta metodología.

Tras el desarrollo del estudio, como puede apreciarse en la imagen de diciembre de 1996, aplicando la misma concepción urbanística con que se diseñó nuestro proyecto, los datos obtenidos sirvieron para la transformación museográfica del yacimiento. Sin excavar, de una forma igualmente no destructiva, entre 1992 y 1994 se procedió al trazado del viario y de la muralla adrianea. Se urbanizó el yacimiento, no para construir, como sucedió en su época, sino para excavarlo de una manera racional mediante el establecimiento de un programa de trabajo a corto, medio y largo plazo (figs. 23 y 24).

\section{CLASIFICACIÓN DE LA TS. CLARA RECOLECTADA}

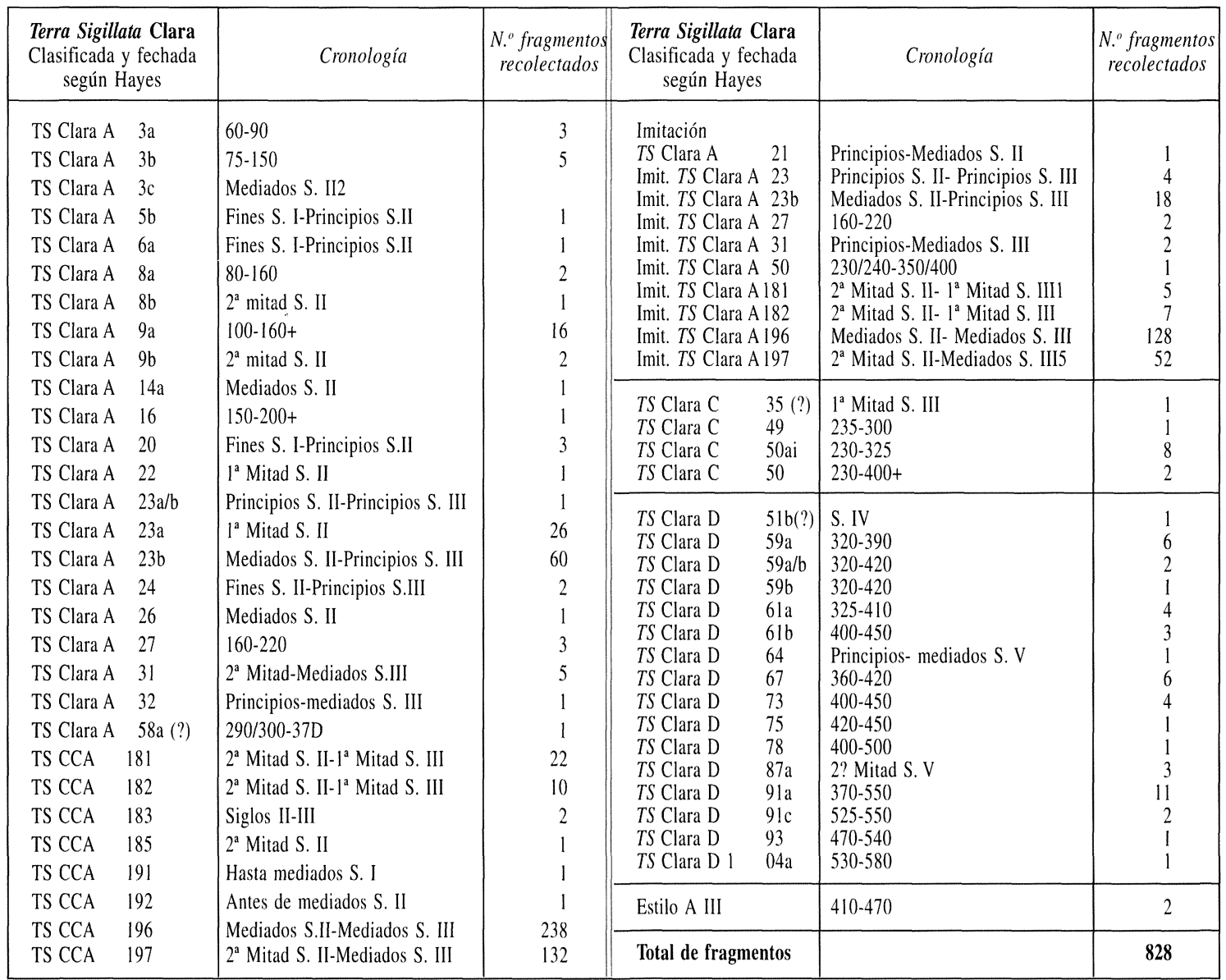


MÁRMOL: PROCEDENCIA, LOCALIZACIÓN Y NÚMERO DE FRAGMENTOS

\begin{tabular}{|c|c|c|c|c|c|c|c|c|}
\hline & TERMAS & GyMNASIUM & $\begin{array}{c}\text { SIN } \\
\text { EDIFICAR }\end{array}$ & $\begin{array}{c}\text { CASAS } \\
\text { (REGIÓN A) }\end{array}$ & $\begin{array}{c}\text { SIN } \\
\text { EDIFICAR }\end{array}$ & $\begin{array}{c}\text { EDIFICIO } \\
\text { PÚBLICO }(\mathrm{K})\end{array}$ & $\begin{array}{c}\text { CaSAS } \\
\text { ReGión B } \\
\text { (OEste) }\end{array}$ & $\begin{array}{c}\text { CASAS } \\
\text { REGIÓN } \\
\text { (ESTE) }\end{array}$ \\
\hline BAETICA & 4 & 8 & & 3 & 11 & 2 & 5 & 1 \\
\hline LUSITANIA & & 1 & & & & & 2 & \\
\hline NUMIDIA & & & & & 2 & & & \\
\hline ITALIA & 8 & 27 & 2 & 19 & 48 & 21 & 13 & \\
\hline PRÓXIMO ORIENTE & 27 & 20 & & 29 & 16 & 20 & 27 & 60 \\
\hline
\end{tabular}

PIEDRA CALIZA: PROCEDENCIA, LOCALIZACIÓN Y NÚMERO DE FRAGMENTOS

\begin{tabular}{|c|c|c|c|c|c|c|c|c|}
\hline & TERMas & Gymnasium & $\begin{array}{c}\text { SIN } \\
\text { EDIFICAR }\end{array}$ & $\begin{array}{c}\text { CASAS } \\
\text { (REGIÓN A) }\end{array}$ & $\begin{array}{c}\text { SIN } \\
\text { EDIFICAR }\end{array}$ & $\begin{array}{c}\text { Edificio } \\
\text { PÚBLICO }(\mathrm{K})\end{array}$ & $\begin{array}{c}\text { CASAS } \\
\text { ReGión B } \\
\text { (OESTE) }\end{array}$ & $\begin{array}{c}\text { CaSAS } \\
\text { REGIÓN B } \\
\text { (ESTE) }\end{array}$ \\
\hline $\begin{array}{l}\text { TEOS (AFRICANA ) } \\
\text { CHEMTOU (YELLOW ANTICO) } \\
\text { LOCAL } \\
\text { TARIFA } \\
\text { CIOS (PORTA SANTA) } \\
\text { TENAROS (ROSSO ANTICO) }\end{array}$ & $\begin{array}{l}1 \\
2 \\
4 \\
6\end{array}$ & 14 & $\begin{array}{l}1 \\
1 \\
1\end{array}$ & $\begin{array}{c}3 \\
1 \\
2 \\
14\end{array}$ & $\begin{array}{c}1 \\
7 \\
1 \\
13 \\
1\end{array}$ & $\begin{array}{l}5 \\
2 \\
3 \\
3\end{array}$ & 9 & $\begin{array}{c}8 \\
12 \\
87\end{array}$ \\
\hline
\end{tabular}

MÁRMOL: PROCEDENCIA DE LAS CANTERAS, LOCALIZACIÓN Y NÚMERO DE FRAGMENTOS

\begin{tabular}{|c|c|c|c|c|c|c|c|c|}
\hline & TERMas & Gymnasium & $\begin{array}{c}\text { SIN } \\
\text { EDIFICAR }\end{array}$ & $\begin{array}{c}\text { CASAS } \\
\text { (REGIÓN A) }\end{array}$ & $\begin{array}{c}\text { SIN } \\
\text { EDIFICAR }\end{array}$ & $\begin{array}{c}\text { EdIFICIO } \\
\text { PÚBLICO }(\mathrm{K})\end{array}$ & $\begin{array}{c}\text { CASAS } \\
\text { REGIÓN B } \\
\text { (OESTE) }\end{array}$ & $\begin{array}{c}\text { CASAS } \\
\text { REGIÓN B } \\
\text { (ESTE) }\end{array}$ \\
\hline $\begin{array}{l}\text { AFYON (PAVONAZZET0) } \\
\text { ALCONERA } \\
\text { ALMADÉN (BAETICA) } \\
\text { BONA (NUMIDIA) } \\
\text { CARRARA (ITALIA) } \\
\text { CIPOLLINO (CARISTOS EUBEA) } \\
\text { GRECO SCRITO DE IPONA (NUMI- } \\
\quad \text { DIA) } \\
\text { LOCAL (BAETICA) } \\
\text { GRECO SCRITO DE EFESO (OPACO) } \\
\text { PIGMENTO ASIA } \\
\text { GRECO SCRITO DE EFESO } \\
\quad \text { (TRANSPARENTE) } \\
\text { PROCONNESUS (ASIA MENOR) } \\
\text { ESTREMOZ ROSA PORTUGAL } \\
\quad \text { (LUSITANIA) } \\
\text { SCYROS } \\
\text { PAROS }\end{array}$ & $\begin{array}{c}3 \\
8 \\
87 \\
1\end{array}$ & $\begin{array}{c}1 \\
8 \\
27 \\
14\end{array}$ & 2 & $\begin{array}{c}2 \\
3 \\
19 \\
19\end{array}$ & $\begin{array}{c}1 \\
1 \\
9 \\
1 \\
48 \\
6 \\
1 \\
1\end{array}$ & $\begin{array}{c}4 \\
2 \\
21 \\
12\end{array}$ & $\begin{array}{c}6 \\
3 \\
13 \\
15\end{array}$ & $\begin{array}{l}6 \\
2\end{array}$ \\
\hline
\end{tabular}

Análisis macroscópico efectuado por el Laboratorio para el estudio de los materiales pétreos de la Antigüedad (Aurelio Álvarez e Isabel Rodá). 


\section{BIBLIOGRAFÍA}

ABAD, L. (1982): «Estratigrafía en la "Casa de las Columnas"», en AAVV, Italica (Santiponce, Sevilla). Actas de las primeras jornadas sobre excavaciones arqueológicas en Italica. Excavaciones Arqueológicas en España 21 (Madrid), 135203.

Amores, F.; Rodríguez Hidalgo, J. M. (1987): «Excavaciones de urgencia en la Avenida de Extremadura n. 56 (Santiponce; Sevilla)», Anuario Arqueológico de Andalucía 1985. III. Actividades de Urgencia, 380-5.

Bintliff, J. \& SnOdgrass, A. (1988): «Mediterranean Survey and the City», Antiquity 62, 5771.

BoATwright, M. T. (1997): «Italica and Hadrian's Urban Benefactions», en A. Caballos \& P. León (eds), Italica MMCC, 115-135, Sevilla.

Caballos, A., Marín, J. y Rodríguez Hidalgo, J.M.: Itálica Arqueológica, Sevilla, 1999.

Canto y de Gregorio, A. (1976): «El mosaico del Nacimiento de Venus de Itálica», Habis, 7, 293338, Sevilla.

Chaves, F. 1988, «Hallazgos Numismáticos», en, P. León, Traianeum de Italica, 119-135

Chisvert, N. (1987-1988): «Reflexiones sobre el topónimo y la descripción de edificios italicenses en las obras antiguas», Habis, 18-19, 565 ss., Sevilla.

Clark, A. (1990): Seeing Beneath the Soil, London.

García y Bellido, A. 1949, Esculturas romanas de España y Portugal, Madrid.

García y Bellido, A. (1960): Colonia Aelia Augusta Italica, Madrid.

GonzÁlez, J. (1951): Repartimiento de Sevilla, C.S.I.C., Madrid.

Hayes, J. W. (1972): Late Roman Pottery, London.

Haselgrove, C. (1985): «Inference from ploughsoil artefacts», en C. Haselgrove, M. Millett \& I. Smith (eds.), Archaeology from the Ploughsoil: studies in the Collection and Interpretation of Field Survey Data, Sheffield, 7-29.

Keay, S.; Creighton, J. \& Jordan, D. (1991): «Sampling Ancient Towns», Oxford Journal of Archaeology, 11.3, 275-315.

León, P. (1982): «La zona monumental de la Nova Urbs» en AAVV, Italica (Santiponce, Sevilla). Actas de las primeras jornadas sobre excavaciones arqueológicas en Itálica. Excavacio- nes Arqueológicas en España 121, 97-132, Madrid.

León, P. (1988): Traianeum de Italica, Sevilla.

Luzón Nogue, J. M. (1982): «Consideraciones sobre la urbanistica de la ciudad nueva de Italica», en AAVV, Italica (Santiponce, Sevilla). Actas de las primeras jornadas sobre excavaciones arqueológicas en Itálica. Excavaciones Arqueológicas en España 121, 77-95, Madrid.

Pellicer, M. (1982): «Excavaciones en (1978-79). Murallas, cloacas y cisterna» en AAVV, Italica (Santiponce, Sevilla). Actas de las primeras jornadas sobre excavaciones arqueológicas en Itálica, Excavaciones Arqueológicas en España 121, 207-224, Madrid

Pellicer, M. (1998): «Los cortes estratigráficos de Itálica y su contribución al estudio de la dinámica Histórico-Cultural del yacimiento», Boletín de la Real Academia de Bellas Artes Santa Isabel de Hungría, 144-186, Sevilla.

Nielsen, I. (1990): «Thermae et Balneae». The Architecture and Cultural History of Roman Public Baths (2 vols.) Aarhus.

Rodríguez Hidalgo, J. M. (1987-1988): «Reflexiones en torno a la Italica de Adriano», Habis, 1819, 583-9.

Rodríguez Hidalgo, J. M. (1991): «Las casas de los pajaros y de la Exedra», en AAVV, La Casa hispanorromana, 291-302, Zaragoza.

RodríGUEZ HIDALGO, J. M. (1991): «Sinopsis historiográfica del Anfiteatro de Itálica» en Historiografía de la Arqueología y de la Historia Antigua en España (siglos XVII-Xx), pp. 91-94, Madrid.

Rodríguez Hidalgo, J. M.; Keay, S. et al. (1993): «Nueva visión de la Itálica de Adriano» en XIV Congreso Internacional de Arqueología Clásica, pp. 364-365, Tarragona.

Rodríguez Hidalgo, M. \& Keay, S. (1995): «Recent Work at Italica», in, B. Cunliffe \& S. Keay (eds.), Social Complexity and the Development of Towns in Iberia From the Copper Age down to the Second Century AD (Oxford), 395-420.

Rodríguez Hidalgo, J. M. (1997): «La nueva imagen de la Itálica de Adriano», en A. Caballos \& P. León (eds.), Italica MMCC, 87-113, Sevilla.

Travlos, J. (1980): Pictorial Dictionary of Ancient Athens, New York.

Ward-Perkins, J. B. (1972): Arquitectura romana, Milano. 